\title{
Flash Flooding in Arid/Semiarid Regions: Climatological Analyses of Flood-Producing Storms in Central Arizona during the North American Monsoon
}

\author{
LONG YANG \\ School of Geography and Ocean Science, Nanjing University, Nanjing, China, and Department of Civil and \\ Environmental Engineering, Princeton University, Princeton, New Jersey \\ JAMES SMITH AND MARY LYNN BAECK \\ Department of Civil and Environmental Engineering, Princeton University, Princeton, New Jersey \\ EFRAT MORIN \\ Institute of Earth Sciences, Hebrew University of Jerusalem, Jerusalem, Israel
}

(Manuscript received 24 January 2019, in final form 6 April 2019)

\begin{abstract}
Flash flooding in the arid/semiarid southwestern United States is frequently associated with convective rainfall during the North American monsoon. In this study, we examine flood-producing storms in central Arizona based on analyses of dense rain gauge observations and stream gauging records as well as North American Regional Reanalysis fields. Our storm catalog consists of 102 storm events during the period of 1988-2014. Synoptic conditions for flood-producing storms are characterized based on principal component analyses. Four dominant synoptic modes are identified, with the first two modes explaining approximately $50 \%$ of the variance of the $500-\mathrm{hPa}$ geopotential height. The transitional synoptic pattern from the North American monsoon regime to midlatitude systems is a critical large-scale feature for extreme rainfall and flooding in central Arizona. Contrasting spatial rainfall organizations and storm environment under the four synoptic modes highlights the role of interactions among synoptic conditions, mesoscale processes, and complex terrains in determining space-time variability of convective activities and flash flood hazards in central Arizona. We characterize structure and evolution properties of flood-producing storms based on storm tracking algorithms and 3D radar reflectivity. Fast-moving storm elements can be important ingredients for flash floods in the arid/semiarid southwestern United States. Contrasting storm properties for cloudburst storms highlight the wide spectrum of convective intensities for extreme rain rates in the arid/semiarid southwestern United States and exhibit comparable vertical structures to their counterparts in the eastern United States.
\end{abstract}

\section{Introduction}

Flash floods in arid/semiarid regions are of great societal and environmental importance, and yet the hydrology, hydrometeorology, and hydroclimatology of flooding are still poorly understood (e.g., Higgins et al. 2003). In this study, we focus on storms that produce flash floods in the arid/semiarid southwestern United States. Much of this region receives more than half of its mean annual rainfall during the North American monsoon (NAM), which typically begins in late June or early July and extends through September (e.g., Douglas

Corresponding author: Long Yang, yanglong86123@hotmail.com et al. 1993; Adams and Comrie 1997). Our study area centers on the Phoenix metropolitan region in central Arizona (Fig. 1). The region is characterized by complex terrain, including the Mogollon Rim and White Mountains (above $2000 \mathrm{~m}$ ) that extend from northwest to southeast and the low desert (below $300 \mathrm{~m}$ ) to the southwest. The spatial and temporal variability of convection and thunderstorms in central Arizona reflect complicated interactions of synoptic-scale features (e.g., tropical cyclones and their remnants, midlatitude systems, monsoon-related moisture surge along the Gulf of California), organized convective systems (e.g., thunderstorm outflow boundary), and complex terrain (e.g., Maddox et al. 1980; López et al. 1997; Higgins et al. 2004; Svoma 2010; 


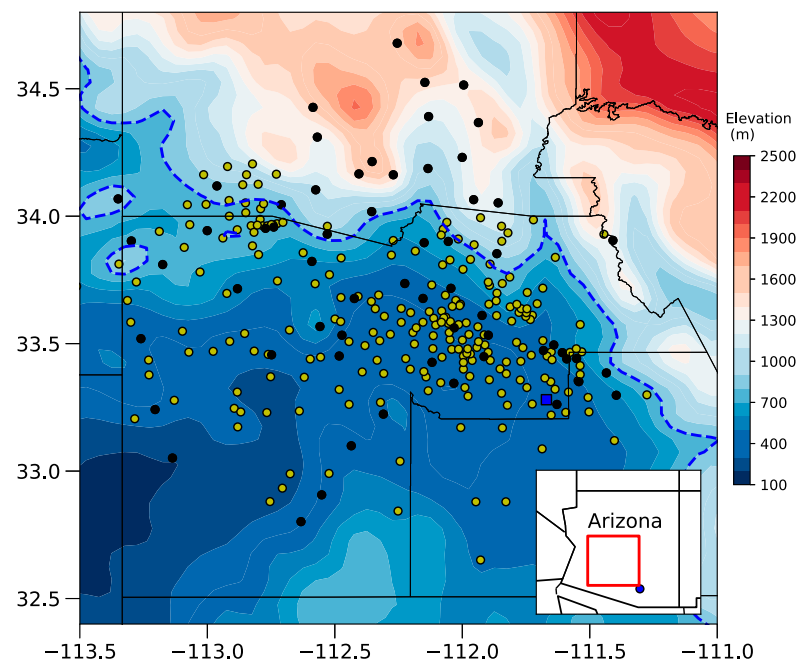

FIG. 1. Rain gauge network (yellow dots) of Maricopa County, AZ. Black dots represent the 65 rain gauges that were initially installed in 1988. The blue square shows the location of the KIWA WSR-88D radar in Phoenix, AZ. Elevation (m) is color shaded with the blue dotted line highlighting the contour of $800 \mathrm{~m}$. The inset shows the boundaries of the state of Arizona (black) and spatial domain of Maricopa County (red). The blue dot shows the location of the radiosonde station in Tucson, AZ.

Corbosiero et al. 2009; Wood and Ritchie 2014; Seastrand et al. 2015; Mazon et al. 2016; Yang and Smith 2018).

Maddox et al. (1995) characterized the synoptic conditions of 27 severe thunderstorms in central Arizona during the North American monsoon period for the years 1978-90 and identified three distinct large-scale patterns of $500-\mathrm{hPa}$ geopotential height. Their results are further confirmed by Mazon et al. (2016) through objective analyses of approximately 400 severe weather events (e.g., hail, lightning, dust storms, thunderstorms) during the years 1993-2010. In this study, we focus on storm events that produce extreme rainfall and flooding in central Arizona during the North American monsoon period (i.e., July-September). Unlike previous studies that rely on weather reports (Maddox et al. 1995) or thermodynamic variables from sounding observations (Mazon et al. 2016), our storm catalog is developed based on a dense, systematic network of rainfall and stream gauging observations (see details in section 3a), and consists of record-breaking flood events in recent decades across this region, notably the 19 August 2014 storm and 8 September 2014 storm (FCDMC 2014a,b). The 19 August 2014 storm, with daily rainfall accumulations (1200 UTC 19 August-1200 UTC 20 August) exceeding $100 \mathrm{~mm}$, determines the upper tail of extreme rainfall and flood frequency distribution over Arizona, and also plays a role in shaping the envelope curve of floods for watersheds smaller than $250 \mathrm{~km}^{2}$ (Yang et al. 2017b; Yang and Smith 2018). The 8 September 2014 storm produced a daily rainfall record (over nearly 115 years) of $84 \mathrm{~mm}$ at Phoenix Sky Harbor airport (FCDMC 2014b) (see the daily weather map at https://www.wpc.ncep.noaa.gov// dailywxmap//index_20140908.html). The two 2014 storms exhibit similar synoptic patterns, characterized by "cutoff low" systems off the coast of California. Cutoff lows contribute approximately $30 \%$ of 1 -h annual maximum precipitation and $20 \%$ of annual precipitation across the interior western United States (Abatzoglou 2016; Barbero et al. 2019). Maddox et al. (1980) found that strong 500-hPa shortwave trough is an important precursor to severe flash flooding over the western United States. Synoptic settings for the two 2014 storms resemble the Type-III pattern as described in Maddox et al. (1995), representing seasonal transitions from the North American monsoon regime to the dominance of midlatitude systems. In this study, we show that this transitional pattern plays a dominant role in extreme rainfall and flooding in the southwestern United States during the NAM period.

Tropical cyclones (and their remnants) in the eastern North Pacific play an important role in extreme rainfall and flooding over the southwestern United States (Corbosiero et al. 2009; Ritchie et al. 2011; Wood and Ritchie 2013, 2014). The concurrent presence of an upper-level trough off the coast of California provides a favorable synoptic environment for the recurvature of tropical cyclones that lead to severe flooding in central Arizona. For instance, the 8 September 2014 storm was associated with the recurvature of Hurricane Norbert (FCDMC 2014b). Previous studies have identified the roles of other synoptic features, for instance, upper-level tropical disturbances ("inverted troughs"; e.g., Pytlak and Goering 2005), in enhanced convective activity over the southwestern United States. The transport of inverted troughs is primarily driven by the pressure gradient along the southern flank of the North American subtropical high and propagates either northeastward or southeastward depending on the orientation of the monsoon ridge (e.g., Mazon et al. 2016). Inverted trough systems enhance synoptic-scale and mesoscale organized convection through both elevated instability and dynamical forcing (Bieda et al. 2009; Lahmers et al. 2016). Contrasting synoptic flow often interact with complex terrain in determining the spatial and temporal rainfall variability in central Arizona. Previous studies show that there is a nocturnal maximum of rainfall in the Phoenix metropolitan region, unlike the diurnal cycle of rainfall in the rest Arizona that peaks in late afternoon (e.g., Balling and Brazel 1987a,b; King and Balling 1994; Svoma 2010). This is possibly due to the preferable timing of a moisture surge from the Gulf of California 
that leads to the destabilization of the atmosphere, frequent location of convergence, and/or propagation of existing convective systems (e.g., Heinselman and Schultz 2006; Mejia et al. 2016; Seastrand et al. 2015; Belachsen et al. 2017; Armon et al. 2018). In this study, we provide insights into the complex interactions of synoptic conditions, mesoscale processes, and complex terrain in determining spatiotemporal variability of flood-producing storms in central Arizona.

Our study also focuses on "cloudburst" storms in the arid/semiarid southwestern United States. Cloudburst storms most commonly refer to "intense rainfall over relatively small areas", (e.g., Parker 1894; Horton 1921; Leopold 1942; Woolley et al. 1946). In this study, we use the criteria of rain rate exceeding $100 \mathrm{~mm} \mathrm{~h}^{-1}$ to distinguish cloudburst storms from very heavy rainfall events [see definition in American Meteorological Society (2019) and discussion in Harris and Lanfranco (2017)]. Due to the small spatial coverages and intense rain rates, cloudburst storms are frequently responsible for destructive flash floods over small watersheds in the southwestern United States. For instance, the 14 September 2015 flood in southern Utah, with the peak discharge of $266 \mathrm{~m}^{3} \mathrm{~s}^{-1}$ over a drainage area of $5.3 \mathrm{~km}^{2}$, is the most deadly natural disaster (i.e., $20 \mathrm{fa}$ talities) in Utah history (Reavy 2015). The flood peak was induced by $12 \mathrm{~mm}$ of rainfall within $7 \mathrm{~min}$ (with the rain rate exceeding $100 \mathrm{~mm} \mathrm{~h}^{-1}$, Smith et al. 2018). Cloudburst storms typically occur during the NAM and are associated with elevated atmospheric moisture content and buoyant instability (Higgins et al. 1997, 2004; Mejia et al. 2016; Luong et al. 2017; Jana et al. 2018). Although previous studies have investigated the physical processes associated with extreme rain rates (e.g., Doswell et al. 1996; Smith et al. 2001; Schumacher and Johnson 2005; Hamada et al. 2015), synoptic-scale analyses can provide important understandings of the large-scale features that are critical for breeding cloudburst storms in arid/semiarid regions. An "unusual" feature of the 14 September 2015 flood in Utah is its exceptional storm motion, with a peak storm speed of $62 \mathrm{~km} \mathrm{~h}^{-1}$ (Smith et al. 2018). Previous studies show flash floods are generally associated with slow-moving precipitation systems (e.g., Maddox et al. 1979; Doswell et al. 1996). Due to the large space-time rainfall variability and transmission losses (Walters 1990; Vivoni et al. 2006), flash flood response in arid/semiarid watersheds shows a strong dependence on storm sizes (i.e., spatial coverage of heavy rain rates; e.g., Syed et al. 2003; Morin et al. 2006; Morin and Yakir 2014; Yang et al. 2017b). In this study, we characterize the structure and evolution of cloudburst storms in central Arizona, shedding light on the key storm ingredients for flash flood response in the arid/semiarid southwestern United States.

Our study is principally motivated by Maddox et al. (1980) proposing that "subtle features often interact to produce flash floods" over the western United States. Multiscale characterizations (i.e., synoptic scale, mesoscale, storm scale) of flood-producing storms in central Arizona can shed light on improved understandings on flood hydrometeorology and hydroclimatology in the arid/semiarid southwestern United States. Our analyses are based on high-resolution (15-min) rain gauge observations, stream gauging records, and reanalysis fields. Storm-tracking algorithms together with 3D radar reflectivity fields from the Weather Surveillance Radar1988 Doppler (WSR-88D) radar at Phoenix will be used to characterize the Lagrangian properties of floodproducing storms. We focus on a comprehensive sample of flood-producing storms in central Arizona during the North American monsoon period. Climatological analyses of flood-producing storms in central Arizona provide useful guidance on improved mitigation and adaptation strategies for flash flood hazards over the Phoenix metropolitan region.

The paper is structured as follows. In section 2, we describe rainfall and streamflow observations used for developing the catalog of flood-producing storms in central Arizona during NAM, along with reanalysis fields and methods for storm tracking analyses. Results and discussions are provided in section 3, including synoptic-scale (section 3c), mesoscale (section 3b), and storm-scale (section $3 \mathrm{e}$ ) characterization of floodproducing storms in central Arizona during the NAM period. Summary and conclusions are presented in section 4 .

\section{Data and methods}

Our analyses are principally based on observations from the rain gauge network maintained by the Flood Control District of Maricopa County (FCDMC), Arizona. The network consists of 310 rain gauges, providing continuous records of 15 -min rainfall accumulation. The 310 rain gauges were installed beginning in the late 1980 s, with 65 operational through the entire period (i.e., 1988-2014, see Fig. 1 for locations). The 65 rain gauges are uniformly distributed over Maricopa County. We integrate 15-min rainfall accumulations into hourly and daily time scales for further analyses. The dense rain gauge network provides an exceptional asset to characterize spatial and temporal variability of rainfall in the arid/semiarid southwestern United States (see, e.g., Mascaro 2017). In addition to the rain gauge network, FCDMC provides stage and discharge records for major 

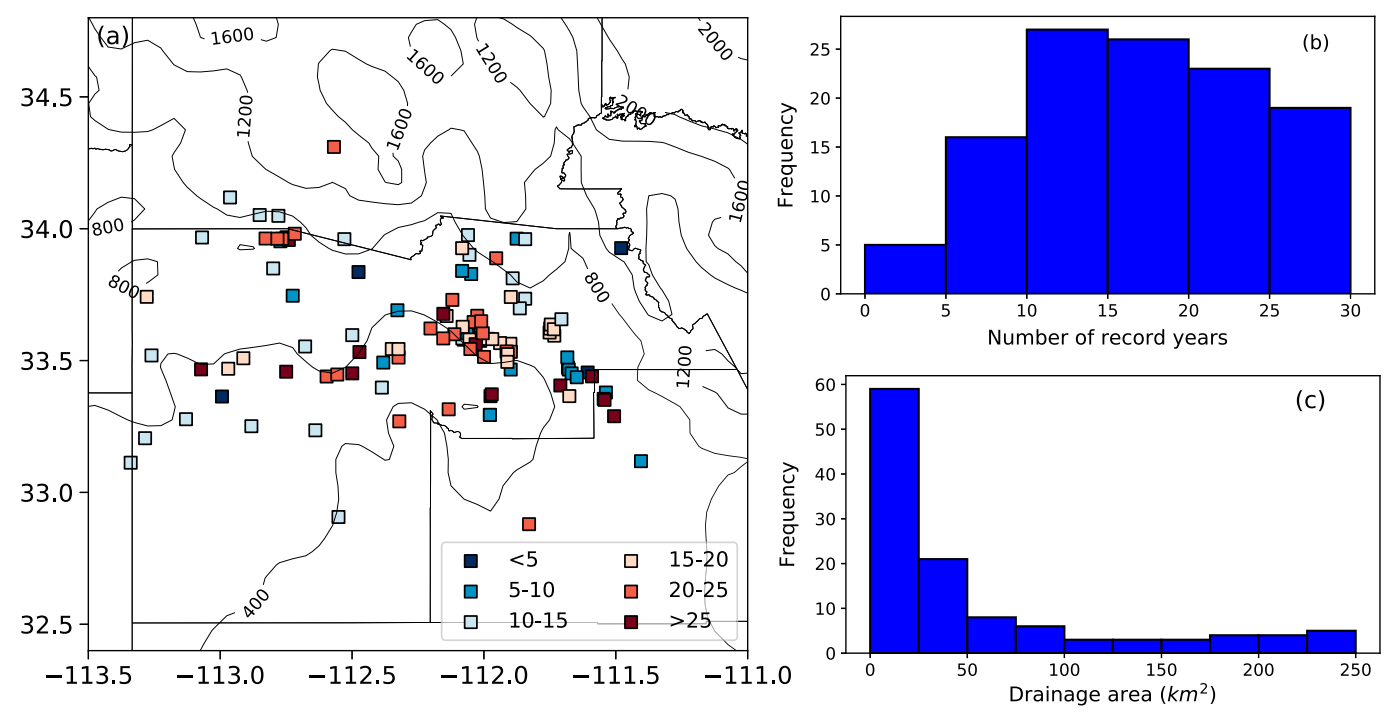

FIG. 2. (a) Spatial distribution of 116 stream gauges with drainage area smaller than $250 \mathrm{~km}^{2}$ over central Arizona. The color scale represents the length of records for each stream gauge. Contours represent elevation with an interval of $400 \mathrm{~m}$. Histograms of (b) record length and (c) drainage area for the 116 watersheds.

stream channels and tributaries in central Arizona (see detailed analyses in Yang et al. 2017b). In this study, we focus on 116 gauged watersheds with drainage area less than $250 \mathrm{~km}^{2}$ (see locations in Fig. 2a). There are 40 watersheds with record lengths of more than 20 years (Fig. 2b), with 89 out of the 116 watersheds smaller than $50 \mathrm{~km}^{2}$ (Fig. 2c). There are 3183 "runoff events" in total across the 116 watersheds during the North American monsoon period of 1988-2014. We term these "runoff events" due to the ephemeral nature of tributaries in the region. There is often an extended period of low flow or no flow between large precipitation events that can trigger the recording of the gauging instruments (similarly also see Yang et al. 2017b). These runoff events, in addition to rain gauge observations, will be used to develop the catalog of flood-producing storms (see section 3 a for details).

We use the Thunderstorm Identification, Tracking, Analysis, and Nowcasting (TITAN; Dixon and Wiener 1993) storm tracking algorithms to examine the structural and evolution properties of flood-producing storms (see also, e.g., Ryu et al. 2016; Yang et al. 2016, 2017b). Storm-tracking analyses are based on 3D reflectivity fields obtained from the KIWA WSR-88D radar in Phoenix, Arizona (see Fig. 1 for locations). We use a reflectivity threshold of $45 \mathrm{dBZ}$ and a volume threshold of $5 \mathrm{~km}^{3}$ to identify convective storm elements (see, e.g., Yang et al. 2016). A small volume threshold is used to account for the limited areal coverage of intense summer precipitation in the southwestern United States (e.g., Leopold 1942). Echo-top height for each storm element is defined as the maximum height of radar reflectivity exceeding $45 \mathrm{~dB} Z$. Each storm element is automatically fitted to an ellipse providing a set of geometrical parameters (e.g., centroid, axis, envelope area). We use the centroid of the ellipse to represent the geographic location of each storm element. The envelope area of each ellipse and the maximum reflectivity within the ellipse are used to represent the size and intensity of each storm element, respectively. Our analyses are restricted to elevations higher than $3 \mathrm{~km}$ above the ground to account for beam blockage to the northeastern quadrant of the radar domain (figure not shown).

We characterize the climatology of thunderstorms in the study region based on cloud-to-ground (CG) lightning observations from the National Lightning Detection Network (NLDN). Only CG lightning strikes with intensities less than $-10 \mathrm{kA}$ are considered in our analyses (see also, e.g., Cummins et al. 1998; Villarini and Smith 2013). The thermodynamic properties of the prestorm environment are described based on sounding observations at Tucson, Arizona (see the inset map of Fig. 1 for location), obtained from the University of Wyoming radiosonde archive (http://weather.uwyo.edu/ upperair/sounding.html). The sounding observations are made twice a day, that is, 0000 and 1200 UTC. We use the 0000 UTC (1700 LST) soundings for its closeness to the most unstable conditions during a day in central Arizona. We use the North American Regional Reanalysis (NARR; see http://www.emc.ncep.noaa.gov/ $\mathrm{mmb} / \mathrm{rreanl}$ for details) fields to examine synoptic conditions and large-scale features of flash flood producing storms in the study region during the North American monsoon period. 


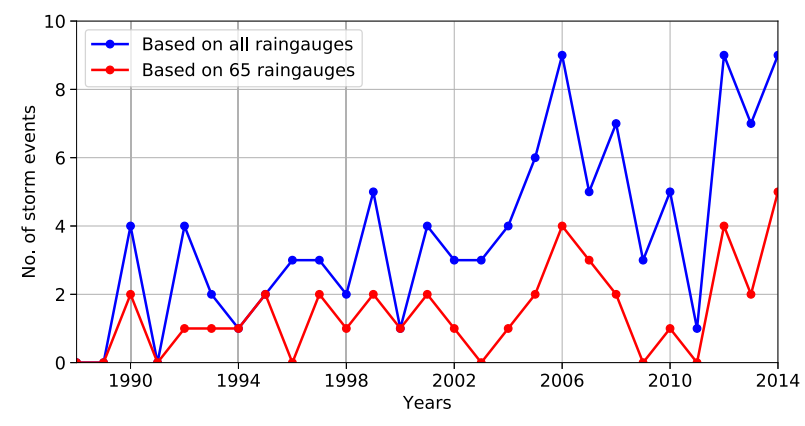

FIG. 3. Interannual variability of the frequency of storm events. The red dotted line represents the frequency of storm events identified based on the 65 rain gauges that are operational during the entire period of 1988-2014.

\section{Results and discussion}

\section{a. Identification of storm days}

The 3183 runoff events are grouped into 543 storm days based on the timing of runoff peak, with each storm day including at least one runoff event. A storm day extends from 1200 to 1200 UTC of the next day. The 543 storm days constitute the initial "pool" of the storm catalog. We further refine the collection of storm days by conditioning on the occurrence of daily rainfall accumulation exceeding $50 \mathrm{~mm}$ for at least one rain gauge (i.e., only the most intense storm events are considered). For consecutive storm days, only the day with the most rain gauges with daily rainfall accumulation exceeding $50 \mathrm{~mm}$ is selected, to avoid repeated selections of multiday storm events. Our final storm catalog has 102 storm days during the NAM period for the years 1988-2014. Each storm day can represent an individual storm event during the study period. The 102 storm events are unevenly distributed within the monsoon season, with more events in July (38) and August (37) than September (26). In terms of interannual variability of storm frequency, there is a weak tendency for more storm events in the recent decade (Fig. 3), corresponding to the strengthening North American monsoon system (e.g., Arias et al. 2012). The changing climatology of extreme rainfall has great implications for the drainage evolution in southwestern U.S. watersheds, due to the important role of intense thunderstorms in the formations of arroyos (characterized with steep slopes and flat floors; e.g., Cooke and Reeves 1976; Graf 1983).

There are a variety of ways to define the storm catalog, for instance, picking up storm days by defining a percentile-based threshold of area-average daily rainfall (99th percentile; e.g., de Vries et al. 2018). In this study, we focus on storms that produce severe flash floods in arid/semiarid regions, some of which exhibit small spatial coverage and may not produce intense rainfall over the entire study region (e.g., Leopold 1942). The criteria used to develop the storm catalog might result in missing storm events with widespread but less intense rainfall. In this study we focus on flash flood hazards over small watersheds; one of our previous studies showed that widespread but less intense storm (which are typically winter storm) in central Arizona made relatively small contributions to flash flood hazards (Yang et al. 2017b). Figure 4 shows the cumulative distribution functions of mean daily rainfall and maximum hourly rainfall over the FCDMC rain gauge network for the days during the entire NAM period of 1988-2014. Mean daily rainfall for the 102 storm days is above 80th percentile of the climatological distribution (with several exceptions that are a bit lower than 80th percentile, Fig. 4a). The storm catalog also includes the days that experience intense hourly rain rates (Fig. 4b). Further examination of the storm catalog from the perspective of flash floods shows that there are 150 runoff events with unit peak discharge exceeding $1 \mathrm{~m}^{3} \mathrm{~s}^{-1} \mathrm{~km}^{-2}$ for
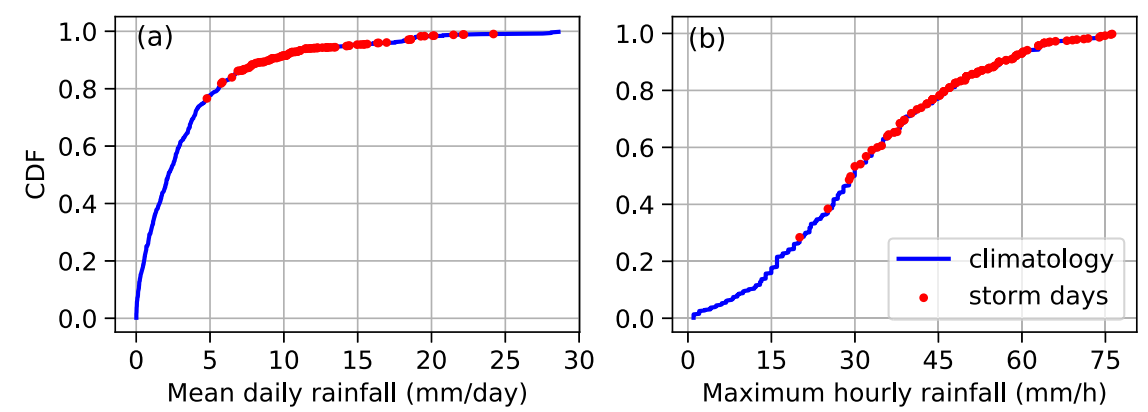

FIG. 4. Cumulative distribution function (blue curves) of gauge-average (a) daily rainfall and (b) maximum hourly rainfall over the FCDMC rain gauge network for all the days during July-September of 1988-2014. Red dots highlight the 102 storm days in the storm catalog. Maximum hourly rainfall denotes the maximum hourly rain rate among all gauges and hours within the day (i.e., 1200-1200 UTC). 
TABLE 1. List of storms that produced record floods over small watersheds with record length of at least 20 years. Only storms occurring during July-September of 1988-2014 are summarized. The values in the parentheses represent number of flood peaks with unit peak discharge exceeding $1 \mathrm{~m}^{3} \mathrm{~s}^{-1} \mathrm{~km}^{-2}$.

\begin{tabular}{|c|c|c|c|c|}
\hline ID & Date & No. of record floods & $\begin{array}{l}\text { Maximum unit peak discharge } \\
\qquad\left(\mathrm{m}^{3} \mathrm{~s}^{-1} \mathrm{~km}^{-2}\right)\end{array}$ & Synoptic type \\
\hline 1 & 15 Aug 1990 & $2(0)$ & 0.39 & EOF2 \\
\hline 2 & 24 Jul 1992 & $1(1)$ & 1.15 & EOF4 \\
\hline 3 & 22 Aug 1992 & $1(1)$ & 1.18 & EOF2 \\
\hline 4 & 15 Jul 1996 & $1(0)$ & 0.09 & EOF2 \\
\hline 5 & 26 Sep 1997 & $2(3)$ & 8.65 & EOF1 \\
\hline 6 & 14 Jul 1999 & $2(2)$ & 2.59 & EOF2 \\
\hline 7 & $14 \mathrm{Jul} 2002$ & $1(1)$ & 1.78 & - \\
\hline 8 & $30 \mathrm{Jul} 2005$ & $2(2)$ & 6.89 & EOF3 \\
\hline 9 & 2 Aug 2005 & $1(4)$ & 3.46 & EOF4 \\
\hline 10 & 24 Aug 2006 & $1(6)$ & 4.06 & EOF2 \\
\hline 11 & 9 Sep 2006 & $1(4)$ & 3.70 & EOF1 \\
\hline 12 & $10 \mathrm{Jul} 2008$ & $1(0)$ & 0.99 & EOF2 \\
\hline 13 & 7 Sep 2012 & $1(3)$ & 3.05 & EOF2 \\
\hline 14 & 9 Sep 2013 & $1(3)$ & 6.05 & EOF4 \\
\hline 15 & 12 Aug 2014 & $1(3)$ & 8.26 & EOF3 \\
\hline 16 & 19 Aug 2014 & $1(17)$ & 5.92 & EOF2 \\
\hline 17 & 8 Sep 2014 & $11(22)$ & 8.50 & EOF2 \\
\hline 18 & 27 Sep 2014 & $1(55)$ & 7.53 & EOF1 \\
\hline
\end{tabular}

the entire database. Out of the 150 runoff events 143 are due to the storm events listed in our storm catalog. In addition, storms that are responsible for record floods (i.e., the largest flood peak in the record history) over 32 watersheds (with record lengths of more than 20 years) are all represented in our storm catalog (see Table 1 for details). The 8 September 2014 storm produced 11 record floods and 22 flood peaks with unit peak discharge exceeding $1 \mathrm{~m}^{3} \mathrm{~s}^{-1} \mathrm{~km}^{-2}$. The storm catalog developed in this study can comprehensively represent the characteristics of storms that produce flash floods in central Arizona during the North American monsoon period. Utilization of high-resolution radar rainfall fields can incorporate storm candidates that produce extreme rainfall in poorly gauged areas, which will be considered in future studies.

We further examine the link between each of the 102 storm events and activities of tropical cyclones in the eastern North Pacific region. The "link" is statistically established when there is a tropical cyclone that moves east of $130^{\circ} \mathrm{W}$ and north of $25^{\circ} \mathrm{N}$ within the 3 -day period prior to the storm event (see also Corbosiero et al. 2009). The timing and position of tropical cyclones for the eastern Pacific are obtained from the National Hurricane Center Best Track Dataset (HURDAT). There are 20 storm events (approximately 20\%) in the storm catalog that are linked with the presence of tropical cyclones (Table 2). The 20 storm events/tropical cyclones are unevenly distributed during the NAM period, with relatively more events in September (11) than July (3) and August (6). We might expect even more storm events in the storm catalog indirectly linked to the remnants of tropical cyclones (Ritchie et al. 2011). Backward moisture tracking analyses can help establish the physical links between extreme rainfall in central Arizona and tropical cyclones in the eastern North Pacific (see, e.g., Yang et al. 2017a).

\section{b. Climatology of flash flood-producing storms}

Figure 5 shows the distribution of precipitable water (PW) and convective available potential energy (CAPE) derived from the sounding station at Tucson during

TABLE 2. List of storms that are linked with the presence of tropical cyclones. The superscripts 1-4 represent the synoptic mode (EOF1, EOF2, EOF3, and EOF4, respectively) cross referenced to the top 10 storms listed in Table 3.

\begin{tabular}{|c|c|c|c|c|c|c|c|}
\hline Date & Name & Date & Name & Date & Name & Date & Name \\
\hline 15 Jul 1990 & Genevieve & 14 Sep 2001 & Ivo & $30 \mathrm{Jul} 2006$ & Emilia $^{4}$ & 24 Aug 2013 & Ivo \\
\hline 22 Aug 1992 & Lester $^{2}$ & 27 Aug 2003 & Ignacio & 3 Sep 2006 & John & 30 Aug 2013 & Juliette $^{4}$ \\
\hline 11 Sep 1996 & Fausto & 5 Sep 2003 & Kevin & 26 Aug 2008 & Julio & 26 Aug 2014 & Marie \\
\hline 25 Sep 1997 & Nora $^{1}$ & 17 Jul 2004 & Blas & $22 \operatorname{Sep} 2010$ & Georgette $^{1}$ & 9 Sep 2014 & Norbert $^{1}$ \\
\hline 19 Sep 1999 & Hilary $^{1}$ & 19 Sep 2004 & Javier & 4 Sep 2012 & John & 17 Sep 2014 & Odile $^{1}$ \\
\hline
\end{tabular}



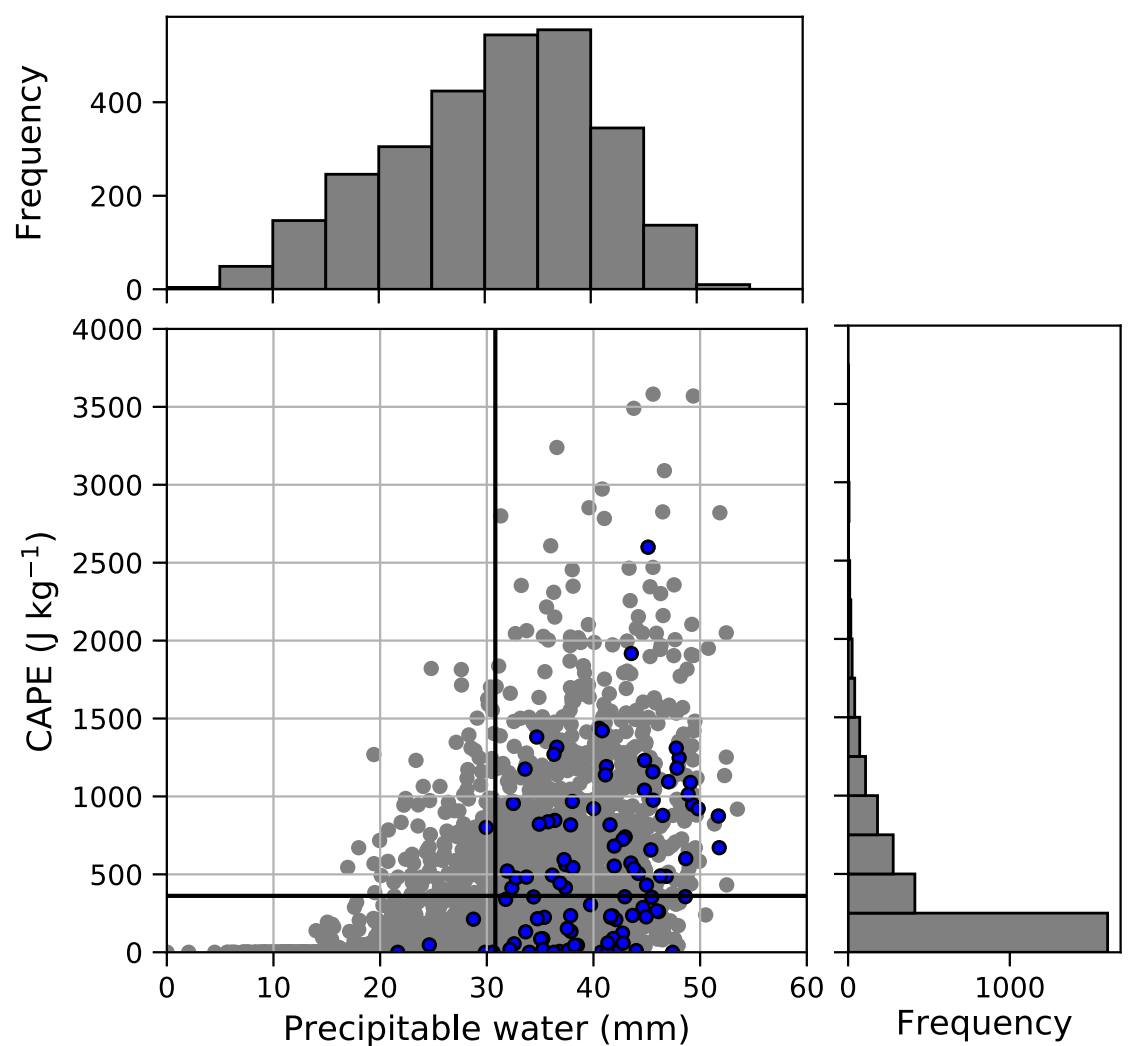

FIG. 5. Scatterplots of PW (mm) vs CAPE $\left(\mathrm{J} \mathrm{kg}^{-1}\right)$ derived from radiosonde observations in Tucson (see Fig. 1 for location), for all days during July-September of 1988-2014. Blue dots highlight the 102 storm days. The mean values of PW and CAPE are respectively indicated by vertical and horizontal black lines. The top and right panels show histograms of PW and CAPE for all the days during July-September of 1988-2014, respectively.

NAM of 1988-2014. The climatological mean values of PW and CAPE are $30.8 \mathrm{~mm}$ and $362 \mathrm{~J} \mathrm{~kg}^{-1}$, respectively. $\mathrm{PW}$ values are above the climatological mean for almost all of the 102 storm days, with a maximum value of $50 \mathrm{~mm}$. High PW is a common feature for the flood-producing storms in central Arizona during the NAM season, highlighting the importance of moisture availability for flood-producing storms in arid/semiarid regions (see also, e.g., Maddox et al. 1979). The maximum CAPE for the 102 storm days is around $2600 \mathrm{~J} \mathrm{~kg}^{-1}$. The majority of the storm days have CAPE values below $1000 \mathrm{~J} \mathrm{~kg}^{-1}$. We use the surface layer in the calculation of CAPE, as opposed to the most unstable CAPE used in Mazon et al. (2016), which might systematically yield lower CAPE values. The frequency distribution of CAPE is skewed toward low values (see also Mazon et al. 2016), indicating that the prestorm environment of flash floodproducing storms in central Arizona is not always associated with high CAPE. This can be partially related to the fact that the sounding profiles in Tucson are not always representative of storm environment in Phoenix, as there are occasions when moisture surge comes from the southwest instead of southeast of Phoenix (e.g., Wallace et al. 1999). The low CAPE values can be also tied to the influence of tropical cyclones and their remnants characterized with low instability but very moist atmospheric profiles. For instance, the CAPE value for the 8 September 2014 storm is around $60 \mathrm{~J} \mathrm{~kg}^{-1}$ (figure not shown). Dixon (2008) shows weak correlations between CAPE and rainfall in central Arizona, even though the likelihood of rainfall occurrence increases with large CAPE. We provide more characterizations of prestorm environment (in terms of spatial distribution of CAPE and PW) based on reanalysis fields in section 3c.

Figure 6 shows the spatial distribution of mean CG flash densities for the 102 storm days. CG flash density is a good indicator of convective activity and storm frequency. The spatial distribution of mean CG flash density is closely linked to topography over central Arizona, indicating strong spatial heterogeneities in storm frequency (Watson et al. 1994; López et al. 1997). CG flash densities peak over the high-elevation region to the northeast of Phoenix including the White Mountains and Mogollon 


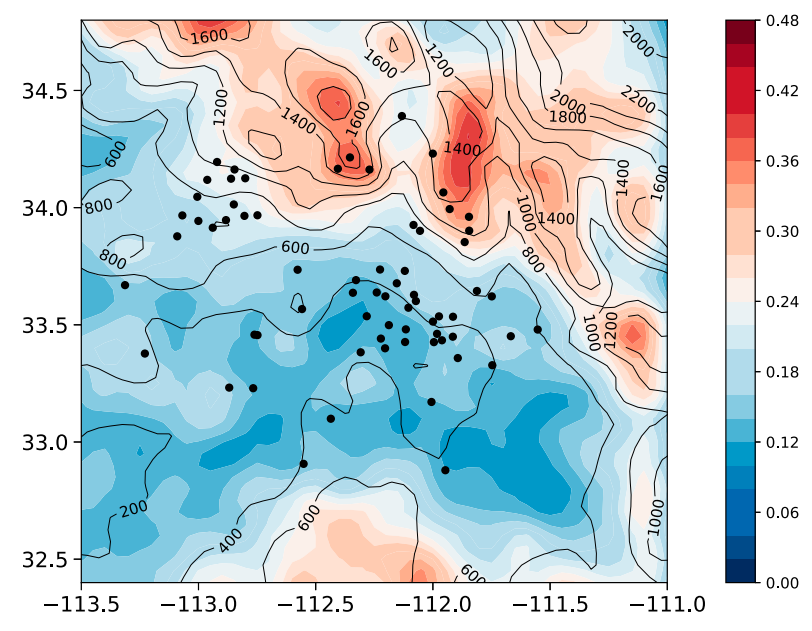

FIG. 6. Mean CG flash density (strikes $\mathrm{km}^{-2}$; shaded) over central Arizona for the 102 storm days. Black dots represent locations of rain gauges with at least one record of the 15-min rain rate exceeding $100 \mathrm{~mm} \mathrm{~h}^{-1}$. Contours represent elevation with an interval of $200 \mathrm{~m}$.

Rim. The peak CG flash density 0.48 strikes $\mathrm{km}^{-2}$ is approximately 4 times larger than the mean flash density over the low desert.

We analyze the climatology of storm properties for 80 out of the 102 storm days based on TITAN algorithms (see details in section 2). The other storm days are beyond the period of radar availability (1994-2014). Consistent with CG flash densities, spatial distributions of storm frequency (as represented by the number of storm elements) show dominant controls of topography (Fig. 7a). There is not strong dependence of storm intensity and storm size on topography (Figs. 7b,c). The mean storm size is less than $65 \mathrm{~km}^{2}$, with maximum reflectivity ranging from 55 to $77 \mathrm{~dB} Z$ (Figs. $7 \mathrm{~b}, \mathrm{c}$ ), indicating that storm elements with intense convective activity can possibly occur in both the low desert and over highelevation terrain. The dominant storm motion for the tracked elements over the 102 storm days is north or northeast, with storm speeds less than $30 \mathrm{~km} \mathrm{~h}^{-1}$ on average (Fig. 7d).

Similar to CG flash densities and storm frequency, spatial distributions of mean daily and hourly rainfall for the 102 storm days also exhibit strong dependence on terrain (correlation coefficients exceeding 0.5 with $p$ values less than 0.01 , see Figs. 8a,c). Topography is the first-order determinant of the climatological pattern of mean rainfall intensity and storm frequency in central Arizona (see also Mascaro 2017). The role of orographic effects in storm frequency and intensity has been extensively investigated in previous studies (e.g., Houze 2012). Contrary to mean daily and hourly rainfall, we found that the spatial distributions of maximum daily and hourly rainfall for the 102 storm days are only weakly linked to topography (Figs. 8b,d). Extreme rainfall in central Arizona can be associated with a variety of physical processes, such as mesoscale convective systems (MCSs; e.g., Hales 1975; McCollum et al. 1995; Pytlak and Goering 2005; Luong et al. 2017), propagation of outflow boundary (McCollum et al. 1995; Vasiloff and Howard 2009), with orographic lifting as an additional factor that potentially contributes to intense convection and extreme rain rates (see also Cannon et al. 2018). We note that even though MCSs are relatively less active in central Arizona (e.g., Farfán and Zehnder 1994; Mejia et al. 2016), their occasional presence can lead to extreme rainfall and flooding (Hales 1975; Griffiths et al. 2009; FCDMC 2014b). MCSs over central Arizona are associated with westward rainfall propagation off the mountains superimposed on a moist, unstable environment. The initiation of MCSs can also be related to the convergence of a strong moisture surge from Gulf of California with an upper-level trough system, for instance, the 8 September 2014 storm (FCDMC 2014b). Upper-tail properties of rainfall and flood frequency distribution in the low desert are determined by less frequent but equally intense storms compared to those over high-elevation terrains.

\section{c. Synoptic characterization of flood-producing storms}

We characterize synoptic conditions for the 102 storm days based on principal component analysis (PCA) for the anomalies of 500-hPa geopotential height averaged over the 24-h period prior to each storm day. PCA has been extensively applied in previous studies (Sheridan 2002; Gochis et al. 2006; Bordoni and Stevens 2006; Wood and Ritchie 2013; Peters and Schumacher 2014; Li and Zhou 2015; Seastrand et al. 2015; Mazon et al. 2016; Pascale and Bordoni 2016). The anomalies of 500-hPa geopotential height of the first four dominant modes explain $66 \%$ of the $500-\mathrm{hPa}$ geopotential height variance. The first four principal components are statistically significant based on North's rule of thumb (North et al. 1982). Our results are repeated using rotated PCA procedures (based on varimax rotation with gamma equal to 1.0), and end up with similar spatial patterns (figures not shown). Figure 9 shows the normalized time series of the first four principal components indicating the strength of each corresponding EOF mode for each individual storm day. To further examine the synoptic patterns of storm days under different EOF modes, we choose the top 10 storm days that exhibit the highest values of each normalized principal component. The dates of the top 10 storm days for each principal component are listed in Table 3. Increasing the number of 
(a) Count

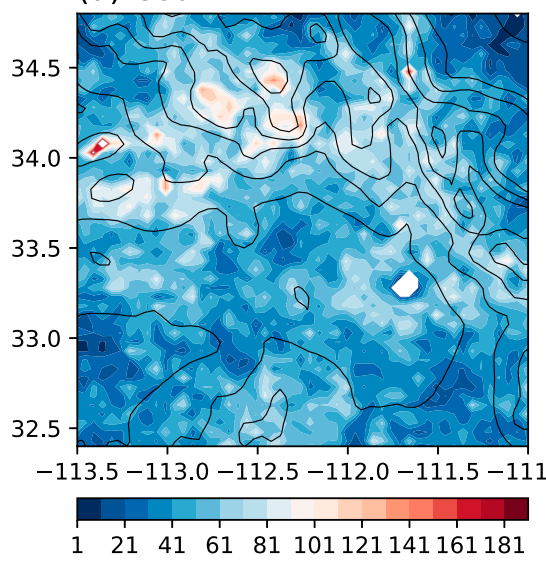

(c) Mean size

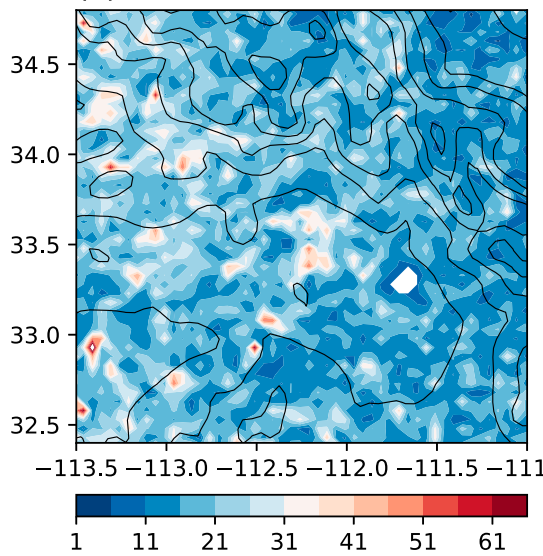

(b) Max dBZ

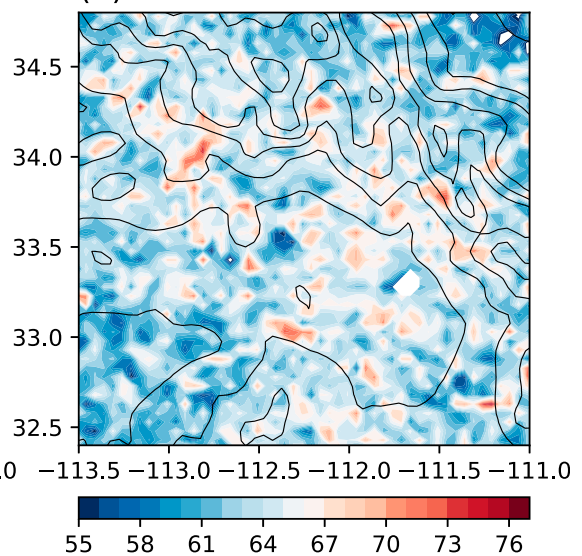

(d) Speed \& Direction

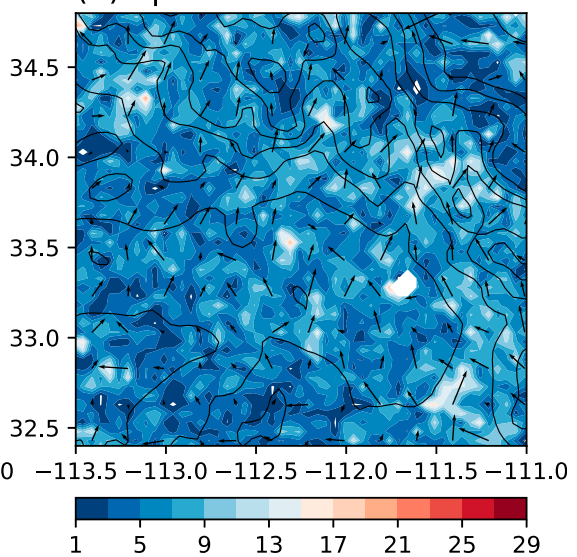

FIG. 7. (a) Total number of storm cells, (b) maximum storm intensity (dBZ), (c) mean storm area $\left(\mathrm{km}^{2}\right)$, and (d) storm speed (shading; $\mathrm{km} \mathrm{h}^{-1}$ ) and motion vectors for the 102 storm days during July-September of 1994-2014. Contours represent elevation with an interval of $200 \mathrm{~m}$.

storm days for each EOF mode can potentially contaminate the results by including samples with relatively weak phases of four principal components, while decreasing the number of storm days can suffer from the internal variability of storm events within each group. We note that there are overlapping storm days among the four modes, especially for EOF1 mode. This is possibly due to the vagaries of upper-level trough (e.g., Mazon et al. 2016). Our analyses are repeated by choosing the top 15 storm days, with only small differences from the results presented below based on top 10 storm days.

The top 10 storm days for the first principal component are composed entirely of September events, while the other three principal components are mixed with events spreading across the entire NAM period. We further construct the composite mean $500-\mathrm{hPa}$ geopotential height fields under each EOF mode by superimposing the mean $500-\mathrm{hPa}$ geopotential height anomalies of the top 10 storm days on the climatological mean 500-hPa geopotential height field (Fig. 10). The first two EOF modes explain approximately $50 \%$ of the $500-\mathrm{hPa}$ geopotential height variance. The spatial patterns of the 500-hPa geopotential height for the first two EOF modes are characterized by strong westerly flow aloft and a retreating North American subtropical high. The contours of $5850 \mathrm{gpm}$ extend southward off the coast of California for the first two EOF modes (Figs. 10a,b). The 5850-gpm contour "breaks" the 500-hPa subtropical ridge off the coast of Baja California (Fig. 10a). There is an anticyclone center in the midlatitude region west of the coast in the second EOF mode (Fig. 10b). Some of the most severe flood-producing storms in central Arizona exhibit strong positive phases of the first two principal components. This is possibly due to the enhanced buoyant instability associated with approaching baroclinic systems and/or the influence of tropical cyclones. A notable 
(a) Mean daily rainfall

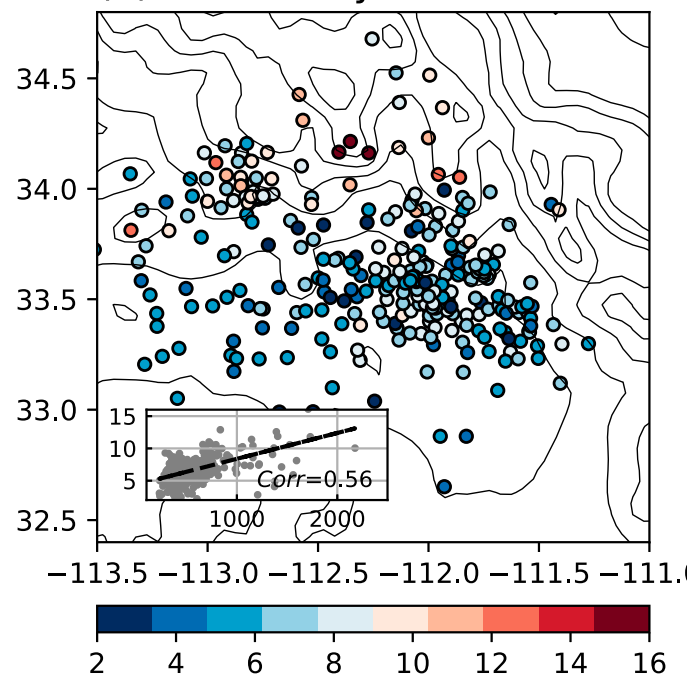

(c) Mean hourly rainfall

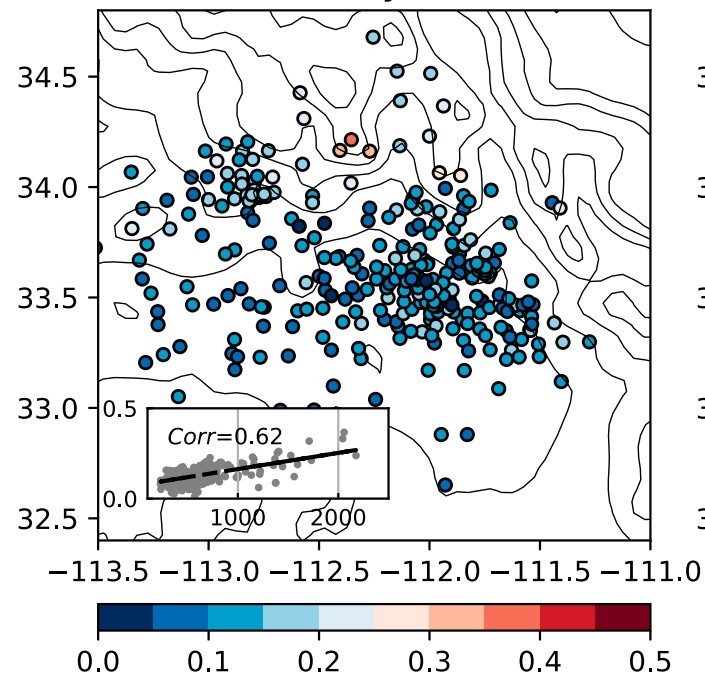

(b) Maximum daily rainfall

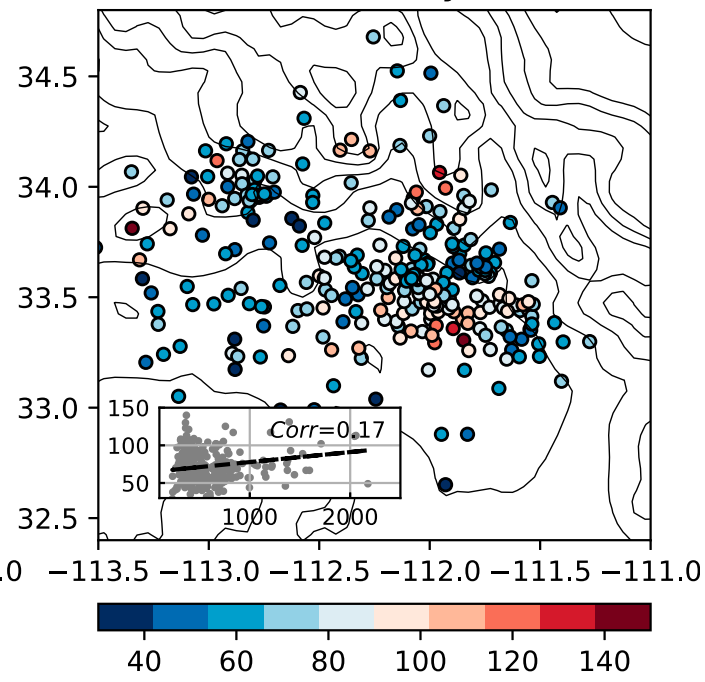

(d) Maximum hourly rainfall

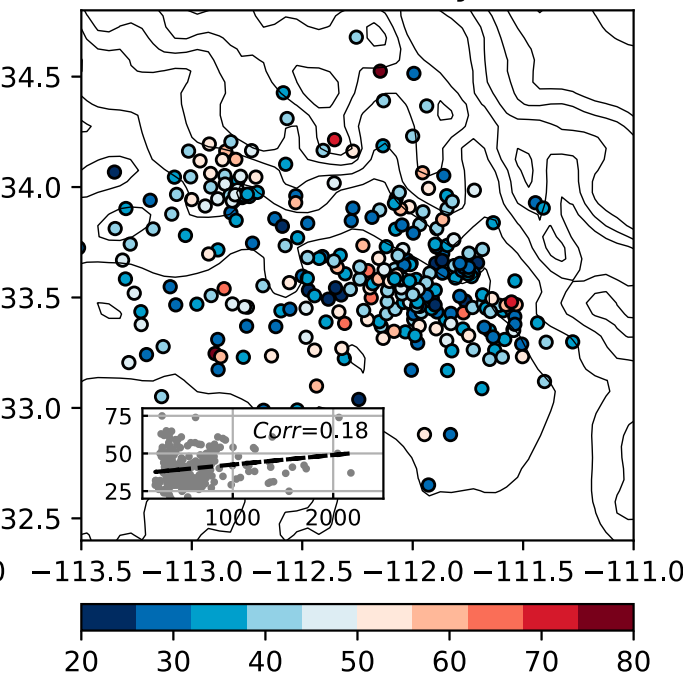

FIG. 8. Spatial distribution of (a) mean daily rainfall $\left(\mathrm{mm} \mathrm{day}^{-1}\right)$, (b) maximum daily rainfall $\left(\mathrm{mm} \mathrm{day}^{-1}\right)$, (c) mean hourly rainfall $\left(\mathrm{mm} \mathrm{h}^{-1}\right)$, and (d) maximum hourly rainfall $\left(\mathrm{mm} \mathrm{h}^{-1}\right)$ for the 102 extreme rainfall days. Contours represent elevation with an interval of $200 \mathrm{~m}$ and increase from southwest toward northeast. The insets show corresponding relations between rainfall statistics $(\mathrm{mm})$ and gauge elevation $(\mathrm{m})$ with linear regression (black line) and Pearson correlation coefficient (Corr).

feature of the 19 August 2014 storm is the slow motion of the "cutoff" low system as shown in Yang and Smith (2018), characterized with CAPE of $1400 \mathrm{~J} \mathrm{~kg}^{-1}$ in the atmospheric profile (Yang and Smith 2018). There are other severe storm events in the storm catalog that exhibit similar synoptic features, that is, slow-moving cutoff low systems off the coast of California, including the 27 September 2014 and 8 September 2014 storm episodes. There are 5 and 3 storms that are related to cutoff low systems in the top 10 storms of the first and second EOF modes, respectively (results not shown). Previous studies highlight the role of cutoff low systems in producing extreme rainfall and flooding (e.g., Marquardt Collow et al. 2016; Pinheiro et al. 2017; Awan and Formayer 2017; Cannon et al. 2018). Even though cutoff low system exhibits minimum frequency during late summer and early autumn in the study region (Oakley and Redmond 2014), our results highlight it as an important synoptic feature of extreme rainfall and flooding in central Arizona during NAM season. There are 5 and 1 out of the top 10 storms under the EOF1 and EOF2 modes, respectively, that are associated with the activities of tropical cyclones in eastern North Pacific (see section 3a and Table 2). The 

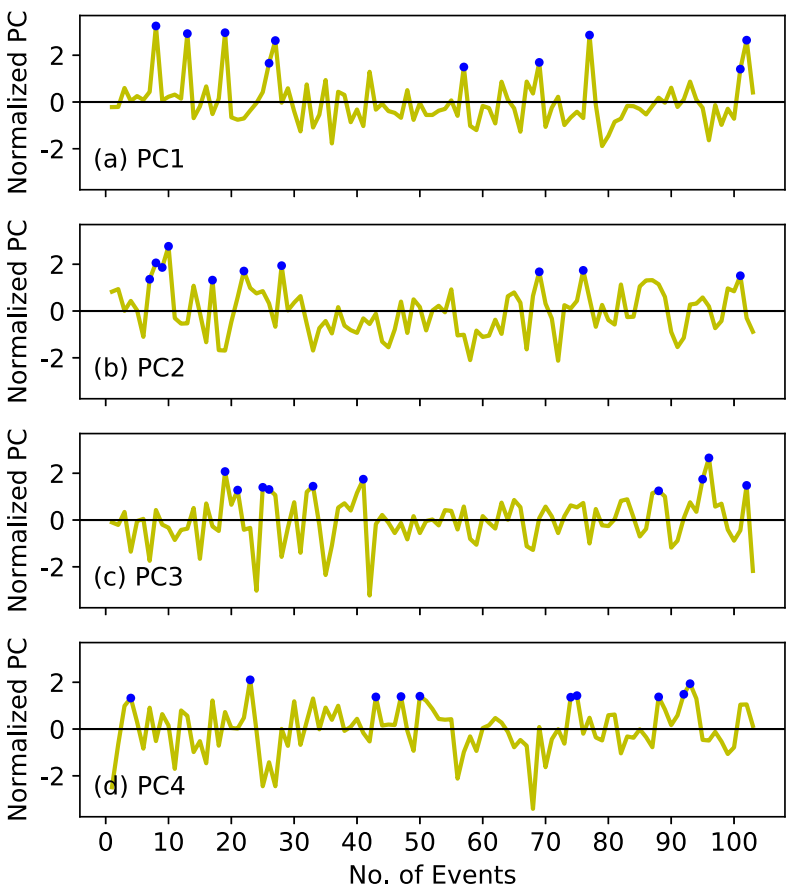

FIG. 9. Time series of the first four principal components (normalized value), (a) PC1, (b) PC2, (c) PC3, and (d) PC4. Blue dots in each subplot represent the top 10 strongest normalized principal component values (see Table 3 for details).

synoptic setting of the EOF1 mode with a southward approaching midlatitude trough provides a favorable environment for the interactions of tropical cyclones with westerly flow aloft, which leads to recurving tracks into central Arizona (Englehart and Douglas 2001; Corbosiero et al. 2009; Ritchie et al. 2011; Wood and Ritchie 2014). The transitional regimes as represented by the first two EOF modes can provide favorable environment for severe weather (e.g., supercell) in central Arizona (Blanchard 2011).

The spatial patterns of composite mean $500-\mathrm{hPa}$ geopotential height for the third and fourth EOF modes are consistent with the type I and II synoptic patterns for severe thunderstorms/weather events as described in Maddox et al. (1980, 1995) and Mazon et al. (2016). The ridge of subtropical high (contour of $5900 \mathrm{gpm}$ ) extends northward and westward in the third EOF mode, with an anticyclone center over the boundary of western Mexico and the Four Corners region (Fig. 10c). For the fourth EOF mode, the entire southwestern United States and Mexico are under control of the subtropical high, with a strong moisture axis extending toward the Gulf of Mexico (Figs. 10d and 11d). For additional descriptions of the two synoptic modes, see Maddox et al. (1995) and Mazon et al. (2016). The synoptic setup of the third and fourth
TABLE 3. Summary of the top 10 storm events that exhibit the strongest positive anomalies of the corresponding principal component.

\begin{tabular}{rllll}
\hline \hline Rank & \multicolumn{1}{c}{ PC1 } & \multicolumn{1}{c}{ PC2 } & \multicolumn{1}{c}{ PC3 } & \multicolumn{1}{c}{ PC4 } \\
\hline 1 & 20 Sep 1992 & 31 Aug 1993 & 15 Jul 2014 & 19 Jul 1999 \\
2 & 25 Sep 1997 & 20 Sep 1992 & 25 Sep 1997 & 9 Sep 2013 \\
3 & 28 Sep 1995 & 29 Aug 2000 & 15 Aug 2004 & 31 Aug 2013 \\
4 & 22 Sep 2010 & 29 Aug 1993 & 9 Jul 2014 & 31 Jul 2010 \\
5 & 17 Sep 2014 & 18 Aug 2010 & 17 Sep 2014 & 30 Jul 2006 \\
6 & 26 Sep 1999 & 14 Jul 1999 & 10 Jul 2002 & 9 Aug 2005 \\
7 & 10 Sep 2008 & 10 Sep 2008 & 15 Sep 1999 & 21 Jul 2013 \\
8 & 19 Sep 1999 & 8 Sep 2014 & 19 Sep 1999 & 24 Jul 2005 \\
9 & 9 Sep 2006 & 22 Aug 1992 & 22 Jul 1998 & 29 Jul 2012 \\
10 & 9 Sep 2014 & 09 Aug 1997 & 21 Jul 2013 & 4 Sep 1990 \\
\hline
\end{tabular}

EOF modes facilitates westward propagation of transient inverted troughs that are frequently associated with organized convection and enhanced rainfall over Arizona (Pytlak and Goering 2005; Bieda et al. 2009; Mejia et al. 2016; Seastrand et al. 2015; Lahmers et al. 2016).

Synoptic conditions of flood-producing storms under different EOF modes are further contrasted by spatial patterns of moisture surge (Fig. 11) together with thermodynamic variables (i.e., PW, CAPE) that characterize the prestorm environment (Fig. 12). Previous studies show that the moisture surge along the Gulf of California is a prominent feature for extreme rainfall in central Arizona (e.g., Higgins et al. 2004; Mejia et al. 2016; Seastrand et al. 2015). The strongest moisture surge occurs under the first EOF mode with the maximum vertically integrated water vapor transport (IVT; integrated from the surface layer to $250 \mathrm{hPa}$; see, e.g., Lavers and Villarini 2013) exceeding $360 \mathrm{~kg} \mathrm{~m}^{-1} \mathrm{~s}^{-1}$, while EOF4 exhibits the weakest moisture surge (around $180 \mathrm{~kg} \mathrm{~m}^{-1} \mathrm{~s}^{-1}$ ) for the 24-h period prior to each storm day (Fig. 11d). A strong moisture surge under the EOF1 mode can be related to disturbances in the tropical regions, including influence of tropical cyclones and their remnants (Ritchie et al. 2011; Wood and Ritchie 2013, 2014).

Compared to the other three EOF modes, the prestorm environment of flood-producing storms under EOF1 mode shows relatively less instability and moisture availability (Figs. 12a,e). In central Arizona the mean departure from the mean values of the 102 storm days is 1.2 standard deviations for PW and 1.0 for CAPE, indicating the significant contribution of strong moisture surge from the Gulf of California. Flood-producing storms under the EOF4 mode, however, are characterized by prestorm environments with abnormally high atmospheric moisture content and moderate instability (Figs. 12d,h). Elevated atmospheric moisture content 
(a) HGT from PCl (Var=30.1\%)

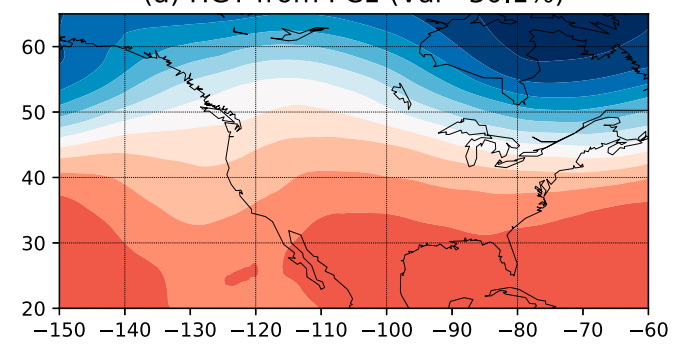

(c) HGT from PC3 (Var=12.4\%)

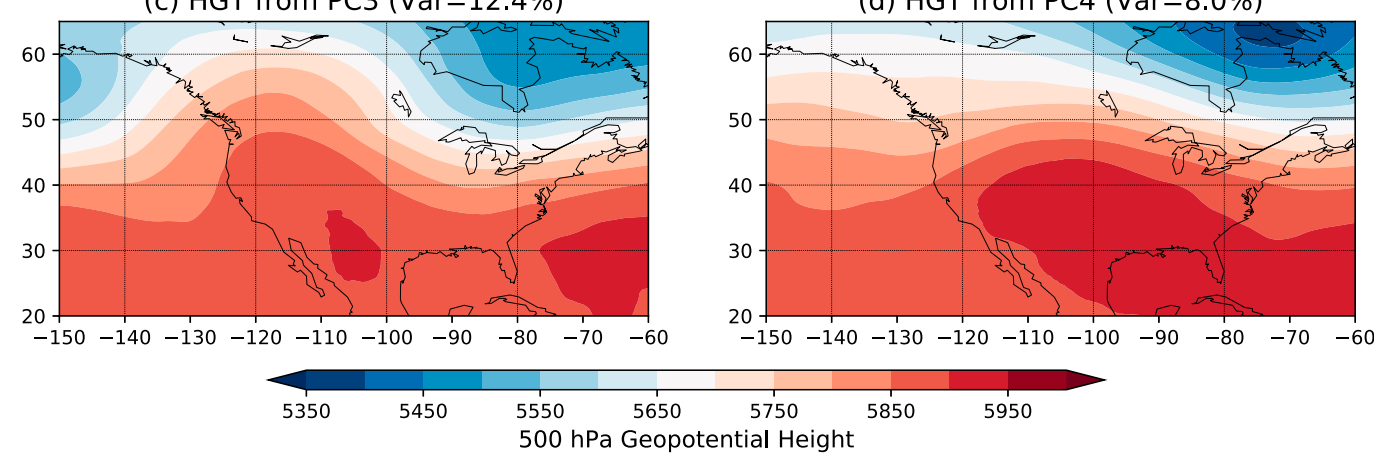

FIG. 10. Geopotential height (gpm) at $500 \mathrm{hPa}$ corresponding to the four dominant EOF modes. Geopotential height field for each EOF mode is constructed by combining the average of 500-hPa height anomalies for the top 10 storm days that exhibit the strongest positive phase of each EOF mode and the mean 500-hPa geopotential height of all 102 storm days. Variance explained by each EOF mode is indicated in the title. might be related to upper-level moisture transport from the Gulf of Mexico (Adams and Comrie 1997; Schmitz and Mullen 1996), but merits additional analyses. The prestorm environment is the most unstable under the EOF2 mode, with relatively weak PW anomalies (Figs. 12b,f). The EOF3 mode is characterized with relatively weak anomalies of both PW and CAPE (Figs. 12c,g). The anomalies shown in Fig. 12 are referenced to the 102 storm days rather than the climatological mean for the entire NAM of 1988-2014. The strong negative anomalies of PW shown in Fig. 12e indicate that the prestorm environment is relatively dry, compared to the other storm days in the storm catalog. Our analyses highlight the contrasting characteristics of prestorm environment for the storms that produce extreme rainfall and flooding in central Arizona during the NAM season.

\section{d. Contrasting spatial organizations of extreme rainfall}

Analyses of moisture transport and the thermodynamic prestorm environment highlight different key components in flood-producing storms, which can consequently lead to contrasting spatial organization of extreme rainfall and flooding in central Arizona. Storm events under the EOF3 mode tend to produce the smallest rainfall coverage (Fig. 13a), with maximum 15-min and 1-h rain rates relatively weaker as well (Figs. 13b,c). This is tied to the weak instability and relatively dry atmosphere in the prestorm environment for storm events under this synoptic mode (Figs. 12c,g). The EOF4 mode provides a favorable environment for relatively large rainfall coverage and extreme rain rates compared to the other three EOF modes. More than 100 rain gauges experience daily rainfall accumulation exceeding $5 \mathrm{~mm}$ on average under the EOF4 mode. The median maximum 15 -min and 1-h rain rates are 120 and $48 \mathrm{~mm} \mathrm{~h}^{-1}$, respectively. There is significant variability in terms of rainfall spatial coverage and rain rate for storm events under the EOF1 and EOF2 modes, compared to the other two modes with the only exception of maximum 15-min rain rates under the EOF2 mode (see the box plots in Fig. 13). Frequency of runoff events within the storm days is closely associated with rainfall coverage and intensity (Fig. 13d).

We further characterize spatial organizations of storm events under different synoptic conditions based on the dense rain gauge network in central Arizona (i.e., top 10 storm events for each group), with special focus on the spatial distribution of maximum rainfall at daily and hourly scales together with rainfall frequency (Figs. 14 and 15). The spatial organization for mean daily rainfall is similar to maximum daily rainfall (figure not shown). EOF3 and EOF4 exhibit similar spatial patterns of 

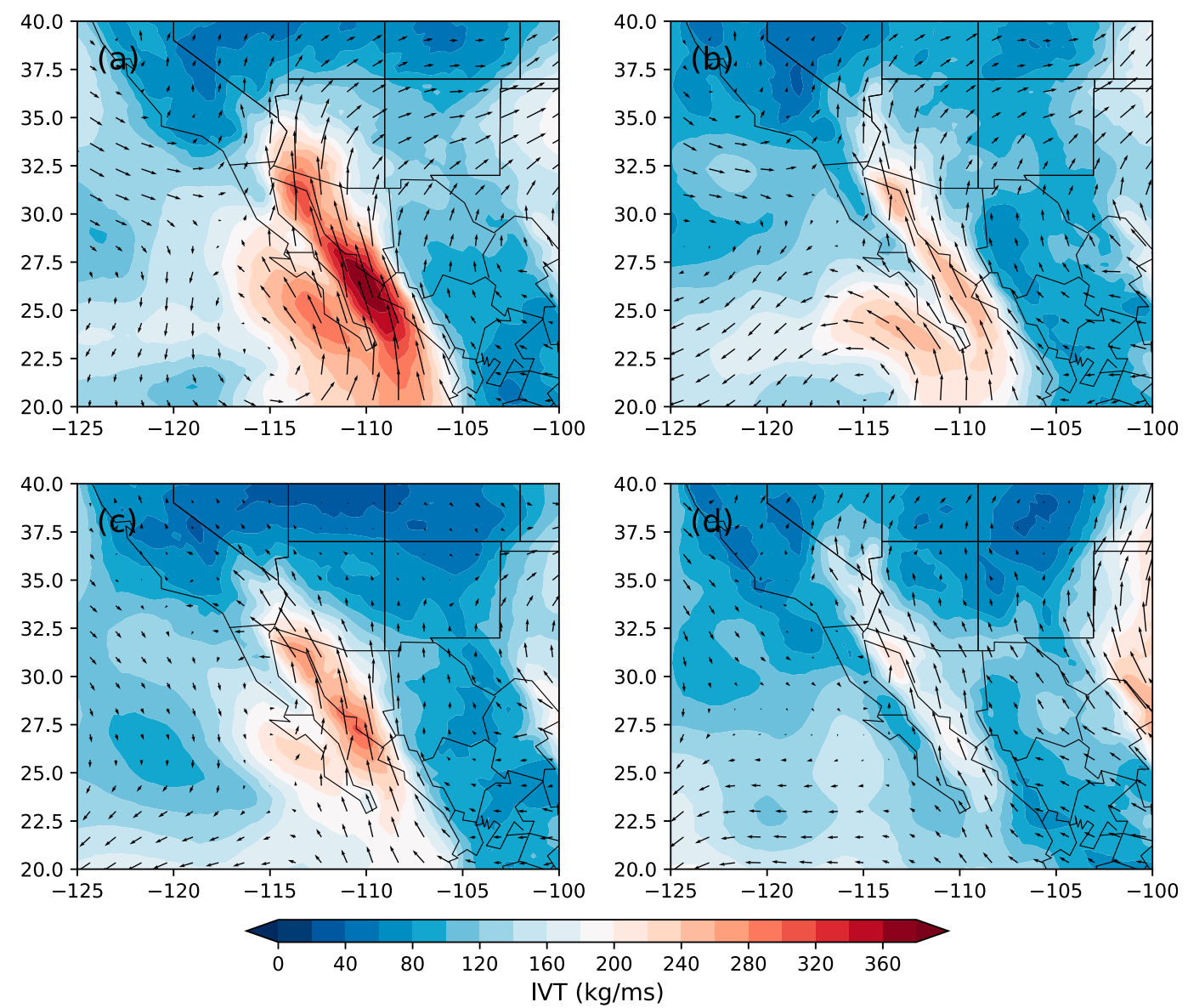

FIG. 11. Composite IVT for the top 10 storm days that exhibit the strongest positive phase of the (a) EOF1,

(b) EOF2, (c) EOF3, and (d) EOF4 modes.

maximum daily rainfall intensity and frequency, with more frequent rainfall distributed over high-elevation regions and extreme values distributed over the foothills (Figs. 14c,d). Maximum daily rainfall under the EOF1 and EOF2 modes can occur in both the low desert and high-elevation terrain (Figs. 14a,b). A notable feature is the relatively larger rainfall frequency under the EOF2 mode than for the EOF1 mode. The EOF2 mode tends to produce extreme rainfall with "recurring" spatial distribution, as opposed to the EOF1 mode, which is associated with large internal variability among storm events. The spatial organization of maximum daily rainfall (Fig. 8b) is not comparable with results in Fig. 14 for maximum daily rainfall under each EOF mode. The departure of daily rainfall under strong synoptic conditions from the climatological mean highlights the important role of synoptic conditions in dictating the spatial organization of extreme daily rainfall in central Arizona (as shown in Fig. 8a). We do not, however, see significant differences among the four synoptic modes in terms of spatial distribution of maximum hourly rainfall
(Fig. 15). The spatial organization of maximum hourly rainfall under strong synoptic conditions is consistent with the climatology for the 102 storm days (Fig. 8d). Contrasts between Fig. 14 and Fig. 15 indicate that synoptic conditions play a role in determining the spatial organization of daily rainfall but not maximum hourly rainfall. Dominant controls of synoptic conditions on daily rainfall organization might be tied to the dynamics of moisture surge, interactions of synoptic flow with topography, propagation of preexisting convection, etc., and persist for the entire storm event (more than several hours). Weak dependence of maximum hourly rainfall on synoptic conditions highlights forecast challenges for severe weather events tied to short-scale convective activity (e.g., dust storms, flash floods) in central Arizona.

There are not contrasting behaviors in terms of storm frequency, maximum reflectivity, and storm size for the storm events under four different synoptic modes (figure not shown). We found, however, significant contrasts in storm motion for the top 10 storm days among the four 

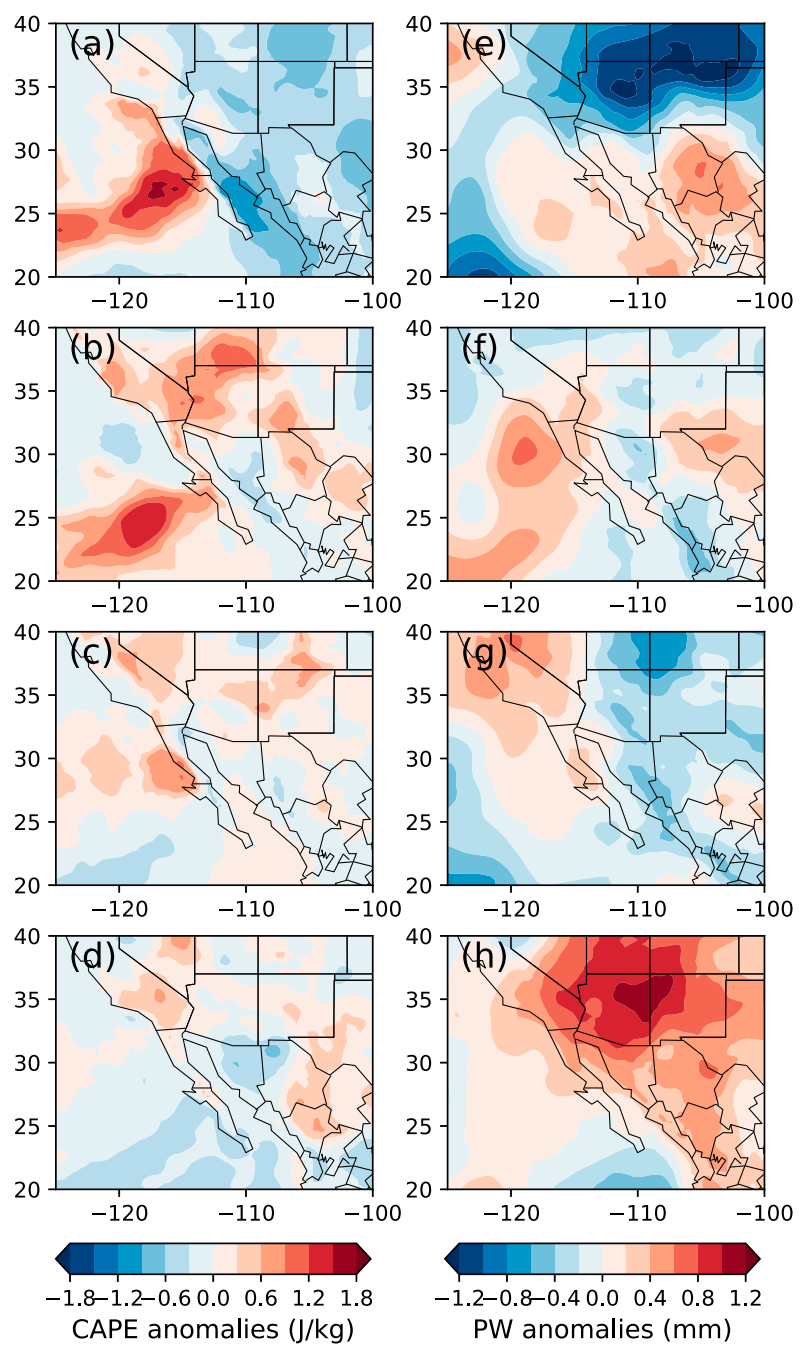

FIG. 12. Normalized (left) CAPE and (right) PW anomalies (i.e., differences between the mean of the top 10 storm days and that of all 102 storm days divided by the standard deviation) for the top 10 storm days that exhibit the strongest positive phase of the (a),(e) EOF1; (b),(f) EOF2; (c),(g) EOF3; and (d),(h) EOF4 modes.

EOF modes (Fig. 16). Storm events under the EOF1 mode stand out with exceptionally large storm speed and small variance of storm direction. Most storm elements under the EOF1 mode are moving from southwest to northeast, with storm speeds exceeding $45 \mathrm{~km} \mathrm{~h}^{-1}$ (Fig. 16). This exceeds the climatological mean storm speed in central Arizona (as shown in Fig. 7d). Fast storm motion under the EOF1 mode can be associated with the sharp pressure gradients due to the interactions of an approaching upper-level trough and retreating North American subtropical high system (see Fig. 10a for details). This synoptic setup is favorable for the recurvature of tropical cyclones and their remnants in the northeastern Pacific region (Wood and Ritchie 2013, 2014). Storm elements under the other three synoptic modes are characterized by relatively large variances in storm directions but with relatively slow storm motion, with storm speeds ranging from 15 to $30 \mathrm{~km} \mathrm{~h}^{-1}$ (Fig. 16). Our analyses show that storm elements with both fast and slow motion can be equally important ingredients for flash flooding in central Arizona.

In addition to storm motion, diurnal cycles of storm frequency show contrasting features among the storm events under different synoptic modes (Fig. 17). There is a weak diurnal cycle of storm frequency for the top 10 storm days under the EOF1 mode (Fig. 17a), while the other three EOF modes show a distinct diurnal cycle (Figs. 17b-d). We further categorize the diurnal cycle of storm frequency according to the location of storm occurrence. We use the elevation contour of $800 \mathrm{~m}$ to distinguish storm occurrence in the mountains (above $800 \mathrm{~m}$ ) and low desert (below $800 \mathrm{~m}$ ). There are no significant differences between the mountains and low desert for the EOF1 mode (Fig. 17a), indicating a weak role of topography in dictating spatial and temporal variability of convection. As we mentioned in section 3c, the activities of tropical cyclones and their remnants play a critical role in characterizing spatiotemporal rainfall variability of storms under EOF1. For the other three EOF modes, however, there are two distinct peaks of storm frequency separated by approximately three hours over the mountains and the low desert (Figs. 17b-d). A notable feature is that storm frequency peaks in early afternoon (2100 UTC, i.e., 1400 LST) in the mountains, but shows variability in peak timing over the low desert. Storm frequency peaks around 0100 UTC (i.e., 1800 LST) for the EOF2 mode, while the peak is about three hours earlier (2200 UTC, i.e., 1500 LST) for the EOF4 mode. Peak storm frequency in the late morning or early afternoon is tied to daytime heating over higher terrain. Convection over higher terrain can cause gravity waves that propagate away from the mountains and can initiate new convection and produce peaks of storm frequency in late afternoon over the low desert (e.g., Bieda et al. 2009; Houze 2012). Contrasting diurnal cycles of convection highlight the intertwined roles of synoptic conditions and topography in dictating spatial organization of convective activity, shedding light on the complicated physical processes of extreme rainfall in central Arizona.

\section{e. Comparative analyses of cloudburst storms under different synoptic conditions}

In this subsection, we examine storm elements that produce intense short-term rain rates (i.e., "cloudburst" storm elements). Based on observations from the rain gauge network, we pick 78 cases of cloudburst storms with a 15 -min rain rate exceeding $100 \mathrm{~mm} \mathrm{~h}^{-1}$ from the 
(a) No. of gauges with daily rain $>5 \mathrm{~mm}$

(b) Maximum 15-min rain rate $(\mathrm{mm})$

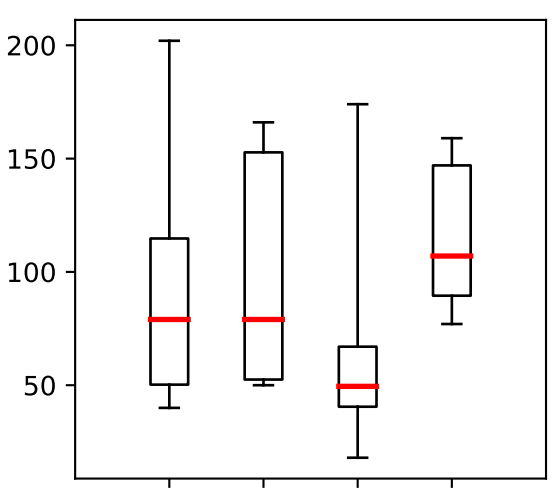

(c) Maximum 1-hour rain rate $(\mathrm{mm})$

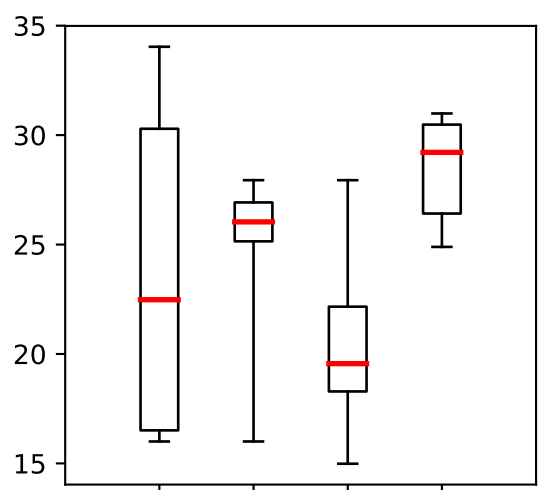

(d) No. of runoff events

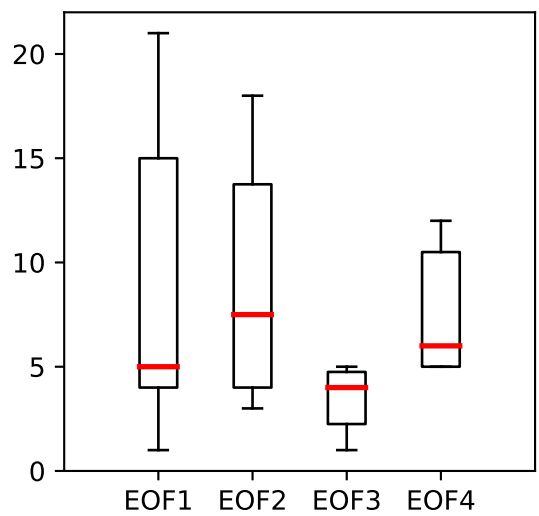

FIG. 13. Summary statistics for the top 10 storm days that exhibit the strongest positive phases of the four EOF modes. The box spans the 25 th and 75 th percentiles, and the whiskers represent the 5th and 95th percentiles. Red lines in the box represent the median values.

102 storm days. A storm case is defined when there is one record of 15 -min rain rate exceeding $100 \mathrm{~mm} \mathrm{~h}^{-1}$ for an individual rain gauge. Figure 6 shows the spatial distribution of rain gauges with cloudburst storm elements observed, indicating a weak dependence of extreme short-term rain rates on topography. For the 8 September 2014 storm, there are seven rain gauges with the 15 -min rain rate exceeding $100 \mathrm{~mm} \mathrm{~h}^{-1}$. Figure 18 shows the composite time series of 15-min rain rate for the 78 cases of cloudburst storms. A notable feature is the sharp increase of rain rates from less than $20 \mathrm{~mm} \mathrm{~h}^{-1}$ to around $110 \mathrm{~mm} \mathrm{~h}^{-1}$ within $15 \mathrm{~min}$. Rain rates drop to around $40 \mathrm{~mm} \mathrm{~h}^{-1}$ within $15 \mathrm{~min}$ following the peak. The maximum $15-\mathrm{min}$ rain rate is $136 \mathrm{~mm} \mathrm{~h}^{-1}$. Sudden bursts of extreme rainfall can lead to severe flash flooding in arid/semiarid regions. The 78 cloudburst storms are unevenly distributed over the four synoptic modes, with 20 and 23 cases for the EOF2 and EOF4 modes, respectively.

We further examine the structure and evolution of storm elements that produce extreme 15 -min rain rates based on analyses of the tracked storm elements using the TITAN algorithms. As the temporal resolution of tracked storm elements is 5-6 min (i.e., temporal interval of radar volume scan), there are approximately two to three storm elements within the 15 -min period. We manually identify storm elements that are responsible for each record of extreme 15 -min rain rate through the utilities embedded in the TITAN algorithms. We extract the maximum values of echo-top height, storm size, maximum reflectivity, and storm speed for the responsible storm elements. Figure 19 shows the contrasting properties of storm elements that produce extreme 15-min rain rate under the EOF2 and EOF4 modes. The median value of echo-top height and maximum reflectivity for cloudburst storms under the EOF4 mode are $12.5 \mathrm{~km}$ and $63.5 \mathrm{~dB} Z$, respectively. The lower boundaries of boxes (25th percentile) for both echo-top height and maximum reflectivity under the EOF4 mode are larger than the corresponding upper boundaries of the boxes (95th percentile) under the EOF2 mode (Figs. 19a,c). The median values of echo-top height and maximum reflectivity for cloudburst storms under the EOF2 mode are $7.1 \mathrm{~km}$ and $54.5 \mathrm{dBZ}$, respectively. Contrasting ranges of echo-top 
(a) EOF1

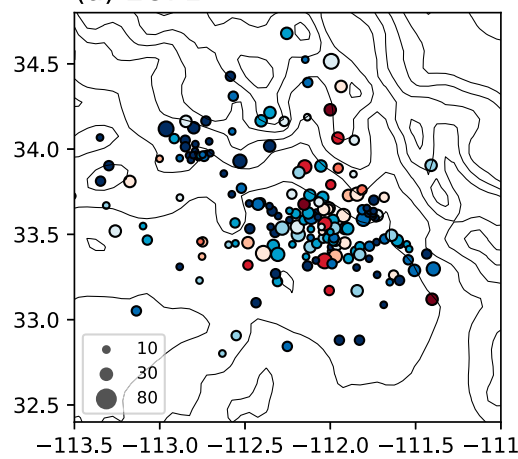

(c) EOF3

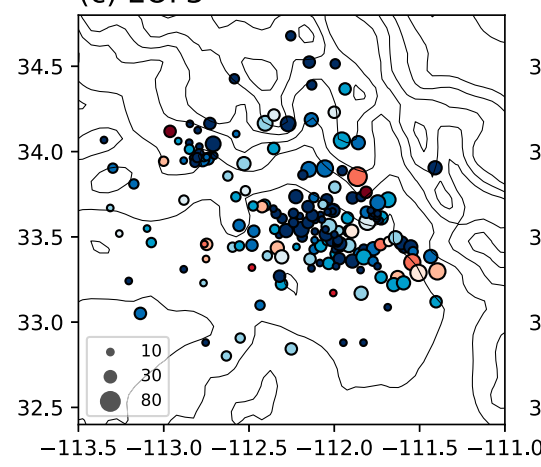

(b) EOF2

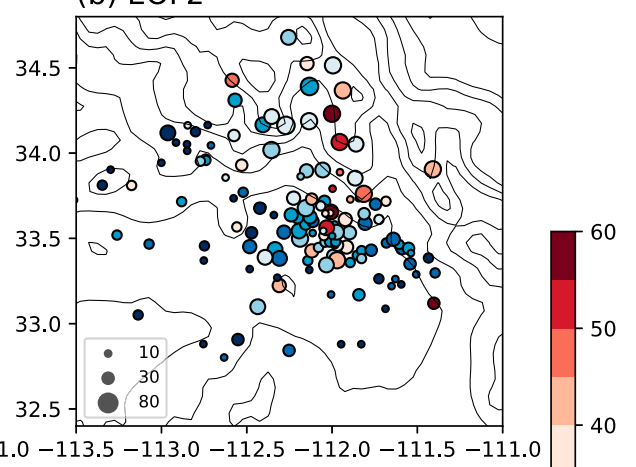

(d) EOF4

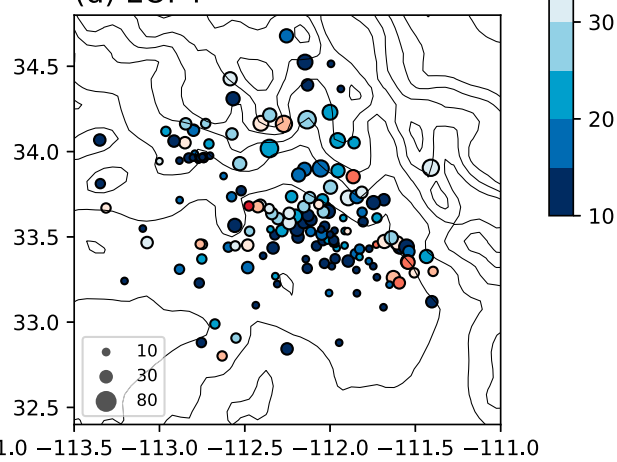

FIG. 14. Spatial distribution of daily rainfall statistics for the top 10 storm days that exhibit the strongest positive phase of the (a) EOF1, (b) EOF2, (c) EOF3, and (d) EOF4 modes. Shaded colors represent maximum daily rainfall accumulation $(\mathrm{mm})$, with the scatter size representing the frequency of days with daily rainfall accumulation exceeding $5 \mathrm{~mm}$. Contours represent elevation with an interval of $200 \mathrm{~m}$.

height and maximum reflectivity for cloudburst storms highlight the wide spectrum of convective intensities associated with extreme rain rates. Cloudburst storms in the arid/semiarid southwestern United States can either be "low-echo centroid" storms or exhibit vertical structures of high echo-top height (see similarly findings for storms in the eastern United States; Yang et al. 2016). The size of storm elements for the cloudburst storms under the EOF2 mode ranges from 20 to $130 \mathrm{~km}^{2}$, with a median value of $30 \mathrm{~km}^{2}$; extreme rainfall under the EOF4 mode tends to be produced by relatively large storm elements (with median values of around $130 \mathrm{~km}^{2}$; Fig. 19b). Contrasting storm sizes lead to the potential for flash flooding over a diverse range of watersheds with drainage area smaller than $200 \mathrm{~km}^{2}$. Previous studies show a strong dependence of flash flood response on spatial coverage of storm cores in arid/semiarid regions, with the most extreme flood peaks contributed by storm cores comparable to or larger than drainage areas (e.g., Yang et al. 2017a). Cloudburst storms under the EOF1 and EOF3 modes show intermediate storm properties (i.e., storm size and intensity) between storms under the EOF2 and EOF4 modest (results not shown). There are no significant differences between EOF2 and EOF4 in terms of storm speed, with only slightly larger speed observed for the cloudburst storms under the EOF2 mode (Fig. 19d). Intense storm elements under the EOF4 mode are associated with a very moist prestorm environment that constrains the entrainment of dry air in lower levels (see Fig. 12h) and is highly conducive to deep moist convection. Based on sounding observations, Maddox et al. (1995) show that downbursts in central Arizona exhibit similar features with the moist microbursts in the southern plains and southeastern United States, due to the exceptionally high mixing ratios in lower levels (also see Willingham and Howard 2010).

\section{Summary and conclusions}

In this study, we examine synoptic conditions and the spatial organization of storms that produce flash floods in central Arizona during the NAM period based on empirical analyses of observations from dense rain gauge and stream gauging networks and radar rainfall reflectivity fields as well as analyses of North American Regional Reanalysis fields. Object-based storm tracking 
(a) EOF1

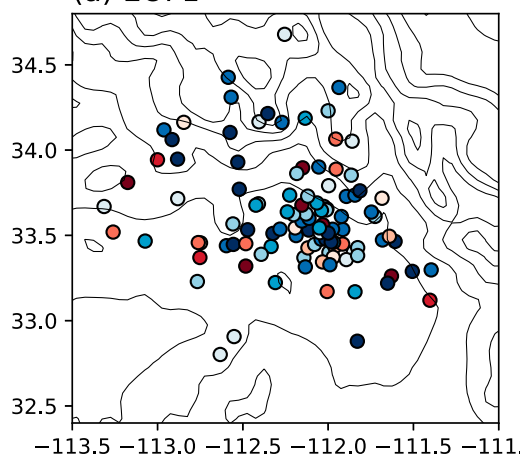

(c) EOF3

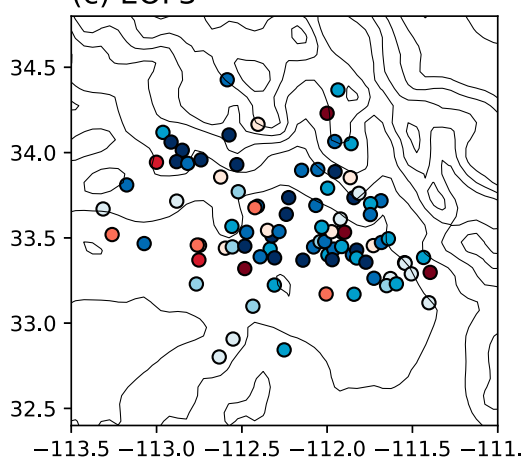

(b) EOF2

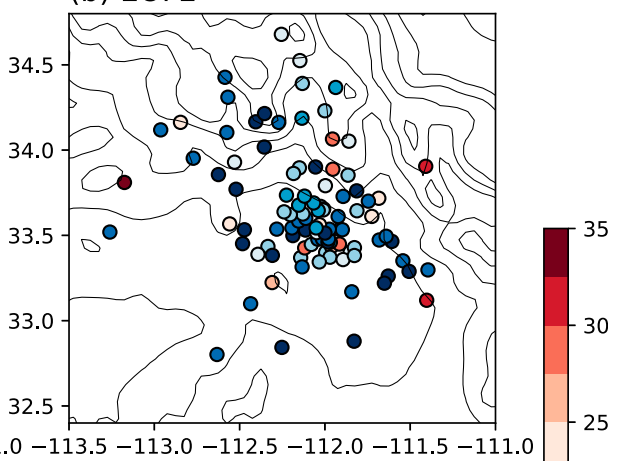

(d) EOF4

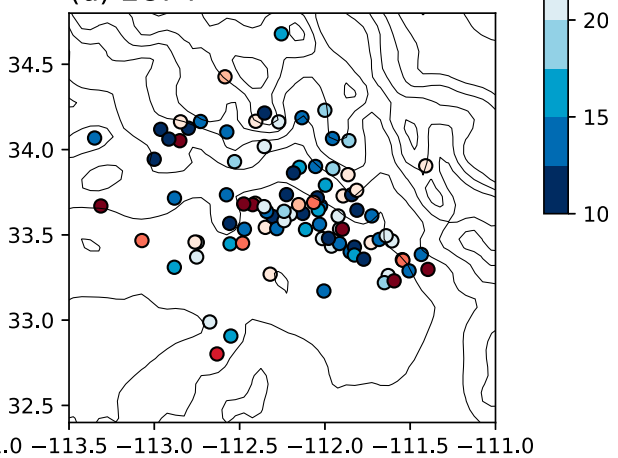

FIG. 15. Spatial distribution of maximum hourly rainfall $\left(\mathrm{mm} \mathrm{h}^{-1}\right)$ for the top 10 storm days that exhibit the strongest positive phase of the (a) EOF1, (b) EOF2, (c) EOF3, and (d) EOF4 modes. Contours represent elevation with an interval of $200 \mathrm{~m}$.

analyses are used to highlight the contrasting structure and evolution of flood-producing storms that are closely tied to the flash flood response in the arid/ semiarid southwestern United States. Even though our analyses are not forecast-oriented, our results provide improved understanding on flood hydrometeorology and hydroclimatology and serve as the basis for better adaptation/mitigation strategies of flash flood hazards in the arid/semiarid southwestern United States. The principal conclusions of this study are summarized as follows:

1) We developed a storm catalog that consists of 102 storm days during the NAM season based on the dense rain gauge and stream gauging network in central Arizona. Each storm day produced at least one rain gauge with daily rainfall exceeding $50 \mathrm{~mm}$. A unique feature of our storm catalog is that we assemble historical storm events based on observed runoff records, which can provide additional insights into atmospheric processes from the perspective of the hydrological response. Climatological analyses of the 102 storm days highlight the dominant role of topography in determining the spatial distribution of mean daily/hourly rainfall as well as the frequency of convective activity during NAM. The prestorm environment for the 102 storm days is characterized with abnormally high atmospheric moisture content but a wide range of values for convective available potential energy.

2) Principal component analyses for the $500-\mathrm{hPa}$ geopotential height fields highlight four dominant synoptic modes for the 102 storm days. The four dominant modes explain $66 \%$ of the $500-\mathrm{hPa}$ geopotential height variance, with the first two modes (EOF1 and EOF2) explaining approximately $50 \%$ of the variance. The first two synoptic modes are characterized by strong westerly winds aloft and the approach of an upper-level trough, indicating the transition from the monsoon regime to the dominance of midlatitude weather systems. This transition pattern of synoptic conditions is responsible for the most widespread rainfall and flash flooding in central Arizona for recent decades. Five out of the top 10 storms under the EOF1 mode are associated with tropical cyclones in eastern North Pacific, highlighting tropical cyclones and their remnants as an important synoptic feature for extreme rainfall and flash flooding in central Arizona. The third and fourth modes identified in this study correspond to the Type II and Type I severe weather 
N

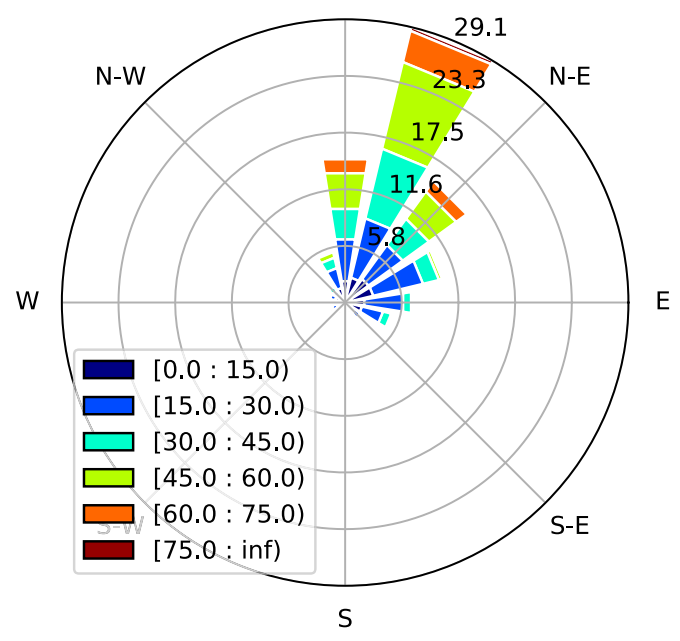

$\mathrm{N}$

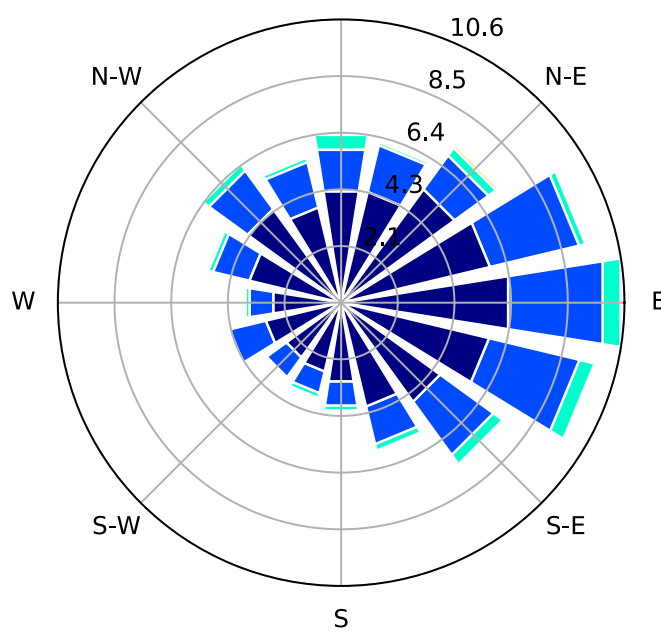

N

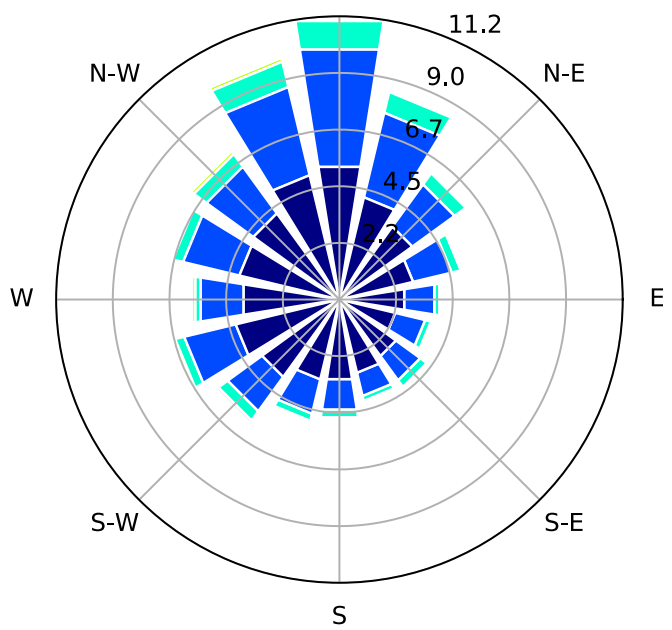

$\mathrm{N}$

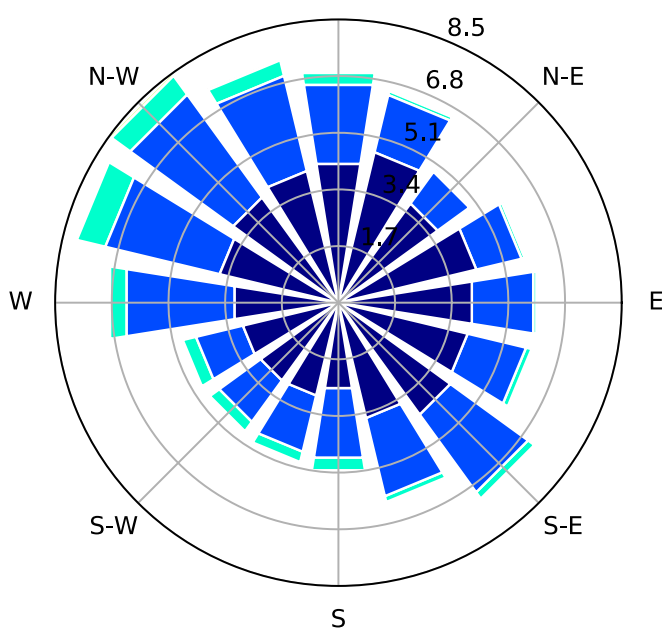

FIG. 16. Wind rose of storm motion and speed for the top 10 storm days that exhibit the strongest positive phase of (top left) EOF1, (top right) EOF2, (bottom left) EOF3, and (bottom right) EOF4. Storm speed ( $\mathrm{km} \mathrm{h}^{-1}$ ) is color shaded, with numbers denoting the frequency of storm occurrence in each category.

patterns as previously described in Maddox et al. (1995) and Mazon et al. (2016).

3) Contrasting features in the prestorm environment for the storm days with four different synoptic conditions point to the dominant processes for extreme rainfall in central Arizona. Storm events under the EOF1 mode are characterized by a strong prior-day moisture surge from the Gulf of California and are also frequently related to tropical cyclones and their remnants in the eastern North Pacific. Storm events under the EOF4 mode have smaller moisture fluxes immediately preceding the storm period. Analysis on composite geopotential height fields and water vapor transport point to the Gulf of Mexico as the main moisture source for storms under the EOF4 mode, but merits additional studies. The EOF2 mode is characterized by the highest CAPE anomalies of the four synoptic modes, possibly related to the approaching upper-level trough, while the EOF3 mode shows neutral or even negative anomalies of CAPE and PW that lead to the smallest spatial coverage and intensity of rainfall.

4) Contrary to the climatology of mean rainfall, the spatial organization of both maximum daily rainfall and maximum hourly rainfall shows a weak dependence on topography. There are weak signatures of interaction between synoptic conditions and topography in determining the spatial organization of maximum daily rainfall but not maximum hourly rainfall, indicating the influence of synoptic pattern on the evolution of storms during the day. Extreme 

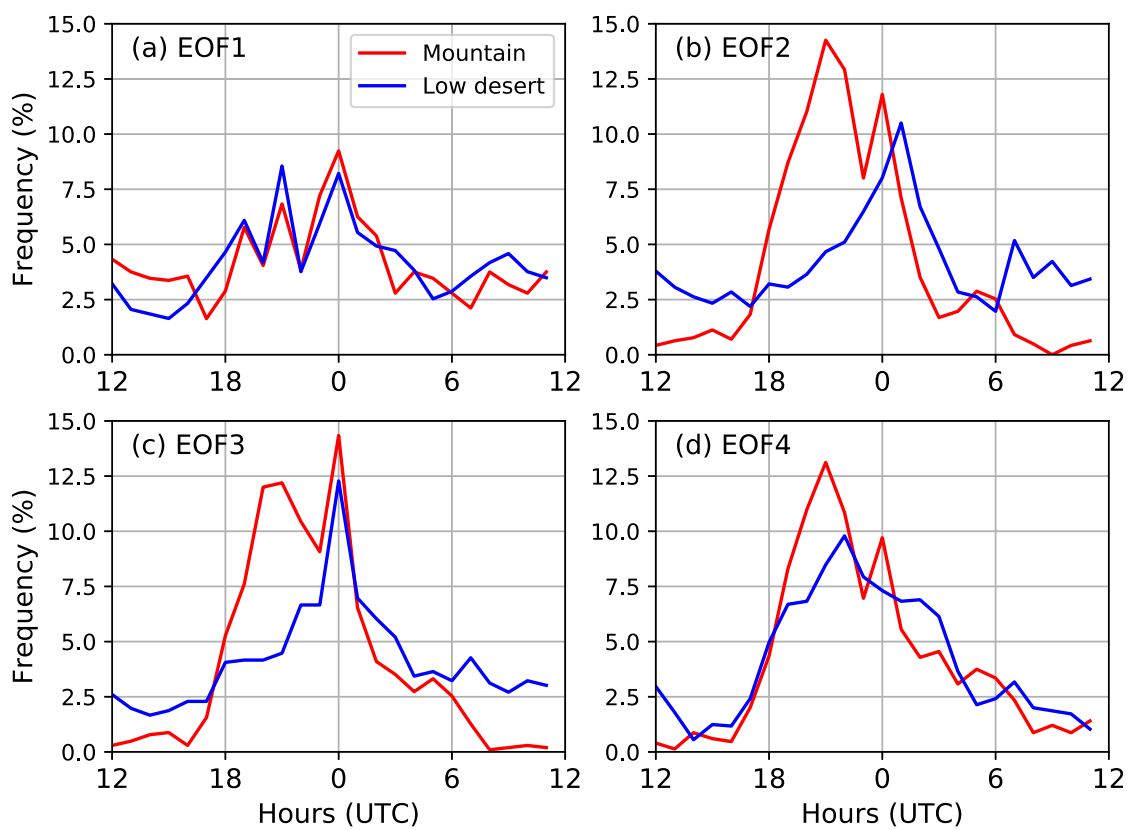

FIG. 17. Diurnal cycle of storm initiation (solid lines) and decay (dashed lines) frequency over mountains (above $800 \mathrm{~m}$, red) and low desert (below $800 \mathrm{~m}$, blue) for the top 10 storm days that exhibit the strongest positive phase of the (a) EOF1, (b) EOF2, (c) EOF3, and (d) EOF4 modes.

rainfall at hourly or subhourly scales, however, is associated with complex physical processes, such as preexisting convection (e.g., MCSs), propagation of outflow boundaries, topographically enhanced convection, and is more weakly tied to synoptic condition. The complexities highlight challenges for operational forecasting and warning of extreme rainfall and flooding in central Arizona.

5) Object-based storm tracking analyses shed light on the contrasts in storm evolution under different synoptic conditions in the arid/semiarid southwestern United States. The climatological mean storm size is smaller than $100 \mathrm{~km}^{2}$, with mean storm speed less than $30 \mathrm{~km} \mathrm{~h}^{-1}$. Diurnal cycles of storm frequency exhibit interrelated roles of synoptic conditions and topography in determining the spatial and temporal variability of convection. Storm events under the EOF1 mode stand out with exceptionally large storm speeds and small variances in storm direction, compared to storm events under the other three synoptic modes. Storm elements with fast storm motion are also important agents for flash flooding in the arid/semiarid southwestern United States. Our results advance understandings on the key storm characteristics for severe flash floods.

6) Cloudburst storm elements that produce extreme 15 -min rain rates exceeding $100 \mathrm{~mm} \mathrm{~h}^{-1}$ show striking contrasts in storm structure under the EOF2 and
EOF4 mode. The median values of echo-top height and maximum reflectivity are $12.5 \mathrm{~km}(7.1 \mathrm{~km})$ and $63.5 \mathrm{dBZ}(54.5 \mathrm{dBZ})$, respectively for the storm elements under the EOF4 (EOF2) mode. Cloudburst storm elements under the EOF2 mode are relatively smaller in size and move faster. More intense storm elements under the EOF4 mode are possibly associated

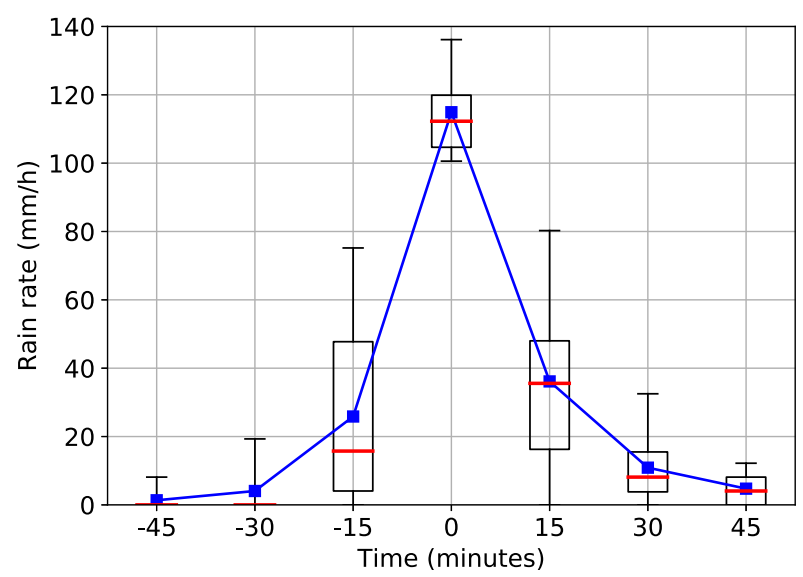

FIG. 18. Composite time series of 15-min rain rate $\left(\mathrm{mm} \mathrm{h}^{-1}\right)$ for 78 cases with peak rain rate exceeding $100 \mathrm{~mm} \mathrm{~h}^{-1}$. Time is centered on peak rain rates. The box spans the 25 th and 75 th percentiles, and the whiskers represent the 5 th and 95 th percentiles. Red lines in the box represent the median values, while blue squares represent the mean values. 
(a) Echo top $(\mathrm{km})$

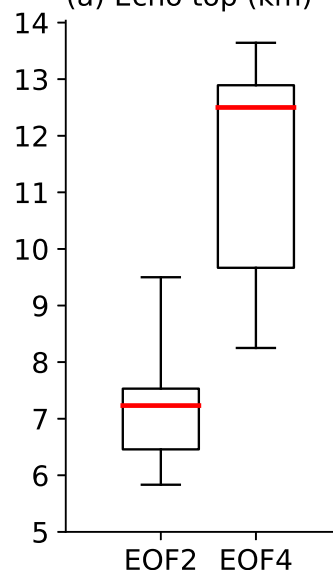

(b) Area $\left(\mathrm{km}^{2}\right)$

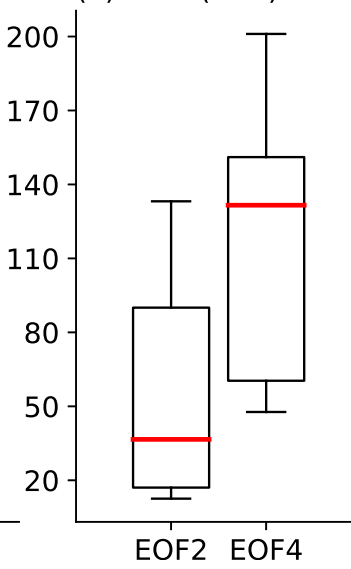

(c) Intensity (dBZ)

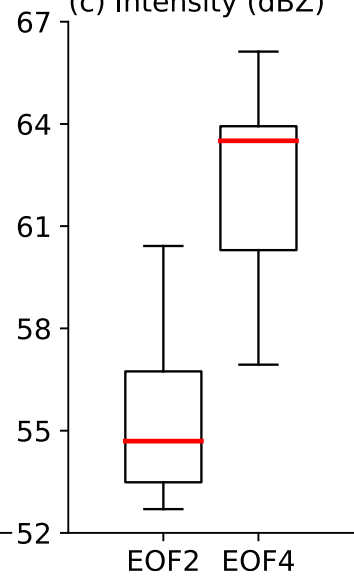

(d) Speed $(\mathrm{km} / \mathrm{h})$

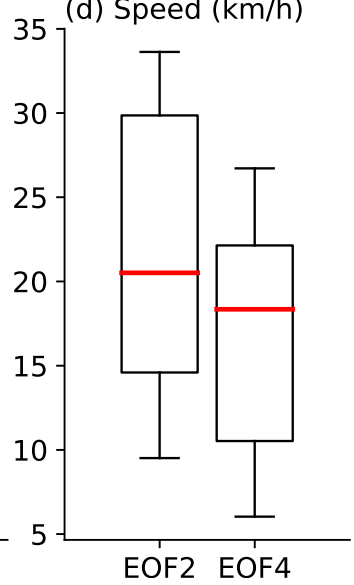

FIG. 19. Boxplots of (a) maximum echo-top height, (b) maximum storm area, (c) maximum reflectivity, and (d) maximum storm speed for the tracked storm elements during the 15 -min period with rain rate exceeding $100 \mathrm{~mm} \mathrm{~h}^{-1}$, categorized by storm environment in the EOF2 and EOF4 modes. The box spans the 25th and 75th percentiles, and the whiskers represent the 5 th and 95 th percentiles. The red lines in the box represent the median values.

with moist storm environments that constrain the entrainment of dry air and are favorable for deep convection. Contrasting storm properties for cloudburst storms in the arid/semiarid southwestern United States highlight the wide spectrum of convective intensity associated with extreme rain rates. Our analyses of cloudburst storms in the arid/semiarid southwestern United States stand in line with studies in the southern plains and southeastern United States (Willingham and Howard 2010) and the eastern coast of United States (Yang et al. 2016), and promote generalized understandings on the physical controls of extreme rainfall for flash floods.

Acknowledgments. We thank Katherine Hirschboeck and two anonymous reviewers for detailed comments and suggestions which substantially improve the manuscript. This research was jointly supported by the United States-Israel Bi-national Science Foundation Grant BSF-2016953, and the National Science Foundation Grants EAR-1632048, AGS-1522492, and CBET-1444758. We would like to acknowledge the Flood Control District of Maricopa County (FCDMC), Arizona, for maintaining the rainfall and stream gauging stations and making observational datasets publicly available.

\section{REFERENCES}

Abatzoglou, J. T., 2016: Contribution of cutoff lows to precipitation across the United States. J. Appl. Meteor. Climatol., 55, 893899, https://doi.org/10.1175/JAMC-D-15-0255.1.

Adams, D. K., and A. C. Comrie, 1997: The North American monsoon. Bull. Amer. Meteor. Soc., 78, 2197-2213, https://doi.org/ 10.1175/1520-0477(1997)078<2197:TNAM>2.0.CO;2.
American Meteorological Society, 2019: Cloudburst. Glossary of Meteorology, http://glossary.ametsoc.org/wiki/Cloudburst.

Arias, P. A., R. Fu, and K. C. Mo, 2012: Decadal variation of rainfall seasonality in the north American monsoon region and its potential causes. J. Climate, 25, 4258-4274, https:// doi.org/10.1175/JCLI-D-11-00140.1.

Armon, M., E. Dente, J. A. Smith, Y. Enzel, and E. Morin, 2018: Synoptic-scale control over modern rainfall and flood patterns in the Levant drylands with implications for past climates. J. Hydrometeor., 19, 1077-1096, https://doi.org/10.1175/JHMD-18-0013.1.

Awan, N. K., and H. Formayer, 2017: Cutoff low systems and their relevance to large-scale extreme precipitation in the European Alps. Theor. Appl. Climatol., 129, 149-158, https://doi.org/ 10.1007/s00704-016-1767-0.

Balling, R. C., and S. W. Brazel, 1987a: Recent changes in Phoenix, Arizona summertime diurnal precipitation patterns. Theor. Appl. Climatol., 38, 50-54, https://doi.org/10.1007/ BF00866253.

$\longrightarrow$, and — 1987b: Diurnal variations in Arizona monsoon precipitation frequencies. Mon. Wea. Rev., 115, 342-346, https://doi.org/10.1175/1520-0493(1987)115<0342:DVIAMP> 2.0.CO;2.

Barbero, R., J. T. Abatzoglou, and H. J. Fowler, 2019: Contribution of large-scale midlatitude disturbances to hourly precipitation extremes in the United States. Climate Dyn., 52, 197-208, https://doi.org/10.1007/s00382-018-4123-5.

Belachsen, I., F. Marra, N. Peleg, and E. Morin, 2017: Convective rainfall in a dry climate: Relations with synoptic systems and flash-flood generation in the Dead Sea region. Hydrol. Earth Syst. Sci., 21, 5165-5180, https://doi.org/10.5194/hess-21-51652017.

Bieda, S. W., C. L. Castro, S. L. Mullen, A. C. Comrie, and E. Pytlak, 2009: The relationship of transient upper-level troughs to variability of the North American monsoon system. J. Climate, 22, 4213-4227, https://doi.org/10.1175/ 2009JCLI2487.1.

Blanchard, D. O., 2011: Supercells in environments with atypical hodographs. Wea. Forecasting, 26, 1075-1083, https://doi.org/ 10.1175/WAF-D-11-00012.1. 
Bordoni, S., and B. Stevens, 2006: Principal component analysis of the summertime winds over the Gulf of California: A gulf surge index. Mon. Wea. Rev., 134, 3395-3414, https://doi.org/ 10.1175/MWR3253.1.

Cannon, F., C. W. Hecht, J. M. Cordeira, and F. M. Ralph, 2018: Synoptic and mesoscale forcing of Southern California extreme precipitation. J. Geophys. Res. Atmos., 123, 13714 13 730, https://doi.org/10.1029/2018JD029045.

Cooke, R. U., and R. W. Reeves, 1976: Arroyos and Environmental Change in the American South-West. Clarendon Press, 226 pp.

Corbosiero, K. L., M. J. Dickinson, and L. F. Bosart, 2009: The contribution of eastern North Pacific tropical cyclones to the rainfall climatology of the southwest United States. Mon. Wea. Rev., 137, 2415-2435, https://doi.org/10.1175/2009MWR2768.1.

Cummins, K. L., E. P. Krider, and M. D. Malone, 1998: The U.S. national lightning detection network and applications of cloud-to-ground lightning data by electric power utilities. IEEE Trans. Electromagn. Compat., 40, 465-480, https://doi.org/ 10.1109/15.736207.

de Vries, A. J., H. G. Ouwersloot, S. B. Feldstein, M. Riemer, A. M. El Kenawy, M. F. McCabe, and J. Lelieveld, 2018: Identification of tropical-extratropical Interactions and extreme precipitation events in the Middle East based on potential vorticity and moisture transport. J. Geophys. Res. Atmos., 123, 861-881, https://doi.org/10.1002/2017JD027587.

Dixon, M., and G. Wiener, 1993: TITAN: Thunderstorm Identification, Tracking, Analysis, and Nowcasting-A radar-based methodology. J. Atmos. Oceanic Technol., 10, 785-797, https://doi.org/ 10.1175/1520-0426(1993)010<0785:TTITAA > 2.0.CO;2.

Dixon, P. G., 2008: Effects of precipitable water and CAPE on precipitation in Southern Arizona. J. Ariz.-Nev. Acad. Sci., 40, 66-73, https://doi.org/10.2181/1533-6085(2008)40[66:EOPWAC]2.0.CO;2.

Doswell, C. A., H. E. Brooks, and R. A. Maddox, 1996: Flash flood forecasting: An ingredients-based methodology. Wea. Forecasting, 11, 560-581, https://doi.org/10.1175/1520-0434(1996) $011<0560$ :FFFAIB $>2.0$. CO;2.

Douglas, M. W., R. A. Maddox, K. Howard, and S. Reyes, 1993: The Mexican monsoon. J. Climate, 6, 1665-1677, https:// doi.org/10.1175/1520-0442(1993)006<1665:TMM>2.0.CO;2.

Englehart, P. J., and A. V. Douglas, 2001: The role of Eastern North Pacific tropical storms in the rainfall climatology of Western Mexico. Int. J. Climatol., 21, 1357-1370, https:// doi.org/10.1002/joc.637.

Farfán, L. M., and J. A. Zehnder, 1994: Moving and stationary mesoscale convective systems over northwest Mexico during the Southwest Area Monsoon Project. Wea. Forecasting, 9, 630-639, https://doi.org/10.1175/1520-0434(1994)009<0630: MASMCS $>2.0 . \mathrm{CO} ; 2$.

FCDMC, 2014a: Storm report: August 19, 2014. Tech. Rep., Flood Control District of Maricopa County, 56 pp., http:// alert.fcd.maricopa.gov/alert/WY14/StormRpt_08192014.pdf.

_ 2014b: Storm report: September 8, 2014. Tech. Rep., Flood Control District of Maricopa County, 89 pp., http:// alert.fcd.maricopa.gov/alert/WY14/StormRpt_09082014.pdf.

Gochis, D. J., L. Brito-Castillo, and W. J. Shuttleworth, 2006: Hydroclimatology of the North American monsoon region in northwest Mexico. J. Hydrol., 316, 53-70, https://doi.org/ 10.1016/j.jhydrol.2005.04.021.

Graf, W. L., 1983: Backgrounds to paleohydrology. The Arroyo Problem: Paleohydrology and Paleohydraulics in the Short Term, K. G. Gregory, Ed., John Wiley \& Sons, 279-302.

Griffiths, P. G., C. S. Magirl, R. H. Webb, E. Pytlak, P. A. Troch, and S. W. Lyon, 2009: Spatial distribution and frequency of precipitation during an extreme event: July 2006 mesoscale convective complexes and floods in southeastern Arizona. Water Resour. Res., 45, 1-14, https://doi.org/ 10.1029/2008WR007380.

Hales, J. E., 1975: A severe southwest desert thunderstorm: 19 August 1973. Mon. Wea. Rev., 103, 344-351, https://doi.org/ 10.1175/1520-0493(1975)103<0344:ASSDTA > 2.0.CO;2.

Hamada, A., Y. N. Takayabu, C. Liu, and E. J. Zipser, 2015: Weak linkage between the heaviest rainfall and tallest storms. Nat. Commun., 6, 6213, https://doi.org/10.1038/ncomms7213.

Harris, A. J., and M. Lanfranco, 2017: Cloudburst, weather bomb or water bomb? A review of terminology for extreme rain events and the media effect. Weather, 72, 155-163, https:// doi.org/10.1002/wea.2923.

Heinselman, P. A., and D. M. Schultz, 2006: Intraseasonal variability of summer storms over central Arizona during 1997 and 1999. Wea. Forecasting, 21, 559-578, https://doi.org/10.1175/ WAF929.1.

Higgins, R. W., Y. Yao, and X. L. Wang, 1997: Influence of the North American monsoon system on the U.S. summer precipitation regime. J. Climate, 10, 2600-2622, https://doi.org/ 10.1175/1520-0442(1997)010<2600:IOTNAM>2.0.CO;2.

- and Coauthors, 2003: Progress in pan American CLIVAR research: The North American monsoon system. Atmósfera, 16, 29-65.

— W. Shi, and C. Hain, 2004: Relationships between Gulf of California moisture surges and precipitation in the southwestern United States. J. Climate, 17, 2983-2997, https:// doi.org/10.1175/1520-0442(2004)017<2983:RBGOCM> 2.0.CO;2.

Horton, R. E., 1921: Thunderstorm-breeding spots. Mon. Wea. Rev., 49, 193-193, https://doi.org/10.1175/1520-0493(1921) 49<193a:TS $>2.0$. CO;2.

Houze, R. A., 2012: Orographic effects on precipitating clouds. Rev. Geophys., 50, RG1001, https://doi.org/10.1029/2011RG000365.

Jana, S., B. Rajagopalan, M. A. Alexander, and A. J. Ray, 2018: Understanding the dominant sources and tracks of moisture for summer rainfall in the southwest United States. J. Geophys. Res. Atmos., 123, 4850-4870, https://doi.org/10.1029/2017JD027652.

King, T. S., and R. C. Balling, 1994: Diurnal variations in Arizona monsoon lightning data. Mon. Wea. Rev., 122, 1659-1664, https:// doi.org/10.1175/1520-0493(1994)122<1659:DVIAML>2.0.CO;2.

Lahmers, T. M., C. L. Castro, D. K. Adams, Y. L. Serra, J. J. Brost, and T. Luong, 2016: Long-term changes in the climatology of transient inverted troughs over the North American monsoon region and their effects on precipitation. J. Climate, 29, 60376064, https://doi.org/10.1175/JCLI-D-15-0726.1.

Lavers, D. A., and G. Villarini, 2013: The nexus between atmospheric rivers and extreme precipitation across Europe. Geophys. Res. Lett., 40, 3259-3264, https://doi.org/10.1002/grl.50636.

Leopold, L. B., 1942: Areal extent of intense rainfalls, New Mexico and Arizona. Eos, Trans. Amer. Geophys. Union, 23, 558-563, https://doi.org/10.1029/TR023i002p00558.

Li, R. C. Y., and W. Zhou, 2015: Interdecadal changes in summertime tropical cyclone precipitation over Southeast China during 1960-2009. J. Climate, 28, 1494-1509, https://doi.org/ 10.1175/JCLI-D-14-00246.1.

López, R. E., R. L. Holle, A. I. Watson, and J. Skindlov, 1997: Spatial and temporal distributions of lightning over Arizona from a power utility perspective. J. Appl. Meteor., 36, 825-831, https://doi.org/10.1175/1520-0450-36.6.825.

Luong, T. M., C. L. Castro, H.-I. Chang, T. Lahmers, D. K. Adams, and C. A. Ochoa-Moya, 2017: The more extreme nature of 
North American monsoon precipitation in the southwestern United States as revealed by a historical climatology of simulated severe weather events. J. Appl. Meteor. Climatol., 56, 2509-2529, https://doi.org/10.1175/JAMCD-16-0358.1.

Maddox, R. A., C. F. Chappell, and L. R. Hoxit, 1979: Synoptic and meso- $\alpha$ scale aspects of flash flood events. Bull. Amer. Meteor. Soc., 60, 115-123, https://doi.org/10.1175/1520-0477-60.2.115.

_- F. Canova, and L. R. Hoxit, 1980: Meteorological characteristics of flash flood events over the western United States. Mon. Wea. Rev., 108, 1866-1877, https://doi.org/10.1175/15200493(1980)108<1866:MCOFFE $>2.0$.CO;2.

—, D. M. McCollum, and K. W. Howard, 1995: Large-scale patterns associated with severe summertime thunderstorms over central Arizona. Wea. Forecasting, 10, 763-778, https:// doi.org/10.1175/1520-0434(1995)010<0763:LSPAWS > 2.0.CO;2.

Marquardt Collow, A. B., M. G. Bosilovich, and R. D. Koster, 2016: Large-scale influences on summertime extreme precipitation in the northeastern United States. J. Hydrometeor., 17, 3045-3061, https://doi.org/10.1175/JHM-D-16-0091.1.

Mascaro, G., 2017: Multiscale spatial and temporal statistical properties of rainfall in central Arizona. J. Hydrometeor., 18, 227-245, https://doi.org/10.1175/JHM-D-16-0167.1.

Mazon, J. J., C. L. Castro, D. K. Adams, H.-I. Chang, C. M. Carrillo, and J. J. Brost, 2016: Objective climatological analysis of extreme weather events in Arizona during the North American monsoon. J. Appl. Meteor. Climatol., 55, 2431-2450, https://doi.org/ 10.1175/JAMC-D-16-0075.1.

McCollum, D. M., R. A. Maddox, and K. W. Howard, 1995: Case study of a severe mesoscale convective system in central Arizona. Wea. Forecasting, 10, 643-665, https://doi.org/10.1175/ 1520-0434(1995)010<0643:CSOASM >2.0.CO;2.

Mejia, J. F., M. W. Douglas, and P. J. Lamb, 2016: Observational investigation of relationships between moisture surges and mesoscale- to large-scale convection during the North American monsoon. Int. J. Climatol., 36, 2555-2569, https://doi.org/10.1002/ joc. 4512 .

Morin, E., and H. Yakir, 2014: Hydrological impact and potential flooding of convective rain cells in a semi-arid environment. Hydrol. Sci. J., 59, 1353-1362, https://doi.org/10.1080/ 02626667.2013 .841315$.

, D. C. Goodrich, R. A. Maddox, X. Gao, H. V. Gupta, and S. Sorooshian, 2006: Spatial patterns in thunderstorm rainfall events and their coupling with watershed hydrological response. Adv. Water Resour., 29, 843-860, https://doi.org/10.1016/ j.advwatres.2005.07.014.

North, G. R., T. L. Bell, R. F. Cahalan, and F. J. Moeng, 1982: Sampling errors in the estimation of empirical orthogonal functions. Mon. Wea. Rev., 110, 699-706, https://doi.org/10.1175/ 1520-0493(1982)110<0699:SEITEO > 2.0.CO;2.

Oakley, N. S., and K. T. Redmond, 2014: A climatology of 500-hPa closed lows in the northeastern Pacific Ocean, 1948-2011. J. Appl. Meteor. Climatol., 53, 1578-1592, https://doi.org/10.1175/ JAMC-D-13-0223.1.

Parker, J. D., 1894: A cloud-burst in Arizona. Amer. Meteor. J., 10 (9), 384.

Pascale, S., and S. Bordoni, 2016: Tropical and extratropical controls of Gulf of California surges and summertime precipitation over the southwestern United States. Mon. Wea. Rev., 144, 2695-2718, https://doi.org/10.1175/MWR-D-15-0429.1.

Peters, J. M., and R. S. Schumacher, 2014: Objective categorization of heavy-rain-producing MCS synoptic types by rotated
Principal Component Analysis. Mon. Wea. Rev., 142, 17161737, https://doi.org/10.1175/MWR-D-13-00295.1.

Pinheiro, H. R., K. I. Hodges, M. A. Gan, and N. J. Ferreira, 2017: A new perspective of the climatological features of upperlevel cut-off lows in the Southern Hemisphere. Climate Dyn., 48, 541-559, https://doi.org/10.1007/s00382-016-3093-8.

Pytlak, E., and M. Goering, 2005: Upper tropospheric troughs and their interaction with the North American monsoon. 19th Conf. on Hydrology, San Diego, CA, Amer. Meteor. Soc., JP2.3, https://ams.confex.com/ams/Annual2005/techprogram/ paper_85393.htm.

Reavy, P., 2015: 16, possibly 20 die in devastating southern Utah flash floods. Deseret News, 15 September, https://www.deseretnews.com/ article/865636814/10-bodies-recovered-in-Hildale-flashflood-as-search-continues-for-3-more.html.

Ritchie, E. A., K. M. Wood, D. S. Gutzler, and S. R. White, 2011: The influence of eastern Pacific tropical cyclone remnants on the southwestern United States. Mon. Wea. Rev., 139, 192210, https://doi.org/10.1175/2010MWR3389.1.

Ryu, Y.-H., J. A. Smith, E. Bou-Zeid, and M. L. Baeck, 2016: The influence of land surface heterogeneities on heavy convective rainfall in the Baltimore-Washington metropolitan area. Mon. Wea. Rev., 144, 553-573, https://doi.org/10.1175/MWRD-15-0192.1.

Schmitz, J. T., and S. L. Mullen, 1996: Water vapor transport associated with the summertime North American monsoon as depicted by ECMWF analyses. J. Climate, 9, 1621-1634, https://doi.org/10.1175/1520-0442(1996)009<1621:WVTAWT $>$ 2.0.CO;2.

Schumacher, R. S., and R. H. Johnson, 2005: Organization and environmental properties of extreme-rain-producing mesoscale. Mon. Wea. Rev., 133, 961-976, https://doi.org/10.1175/ MWR2899.1.

Seastrand, S., Y. Serra, C. Castro, and E. Ritchie, 2015: The dominant synoptic-scale modes of North American monsoon precipitation. Int. J. Climatol., 35, 2019-2032, https://doi.org/ 10.1002/joc. 4104 .

Sheridan, S. C., 2002: The redevelopment of a weather-type classification scheme for North America. Int. J. Climatol., 22, 5168, https://doi.org/10.1002/joc.709.

Smith, J. A., M. L. Baeck, Y. Zhang, and C. A. Doswell, 2001: Extreme rainfall and flooding from supercell thunderstorms. J. Hydrometeor., 2, 469-489, https://doi.org/10.1175/15257541(2001)002<0469:ERAFFS > 2.0.CO;2.

,-- J. Signell, L. Yang, E. Morin, and D. C. Goodrich, 2018: "The paroxysmal precipitation of the desert": Flash floods in the southwestern United States. 32nd Conf. on Hydrology, Austin, TX, Amer. Meteor. Soc., J48.4, https://ams.confex.com/ ams/98Annual/webprogram/Paper334430.html.

Svoma, B. M., 2010: The influence of monsoonal gulf surges on precipitation and diurnal precipitation patterns in central Arizona. Wea. Forecasting, 25, 281-289, https://doi.org/10.1175/ 2009WAF2222299.1.

Syed, K. H., D. C. Goodrich, D. E. Myers, and S. Sorooshian, 2003: Spatial characteristics of thunderstorm rainfall fields and their relation to runoff. J. Hydrol., 271, 1-21, https://doi.org/10.1016/ S0022-1694(02)00311-6.

Vasiloff, S. V., and K. W. Howard, 2009: Investigation of a severe downburst storm near Phoenix, Arizona, as seen by a mobile Doppler radar and the KIWA WSR-88D. Wea. Forecasting, 24, 856-867, https://doi.org/10.1175/2008WAF2222117.1.

Villarini, G., and J. A. Smith, 2013: Spatial and temporal variability of cloud-to-ground lightning over the continental U.S. during 
the period 1995-2010. Atmos. Res., 124, 137-148, https:// doi.org/10.1016/j.atmosres.2012.12.017.

Vivoni, E. R., R. S. Bowman, R. L. Wyckoff, R. T. Jakubowski, and K. E. Richards, 2006: Analysis of a monsoon flood event in an ephemeral tributary and its downstream hydrologic effects. Water Resour. Res., 42, W03404, https://doi.org/10.1029/ 2005WR004036.

Wallace, C. E., R. A. Maddox, and K. W. Howard, 1999: Summertime convective storm environments in central Arizona: local observations. Wea. Forecasting, 14, 994-1006, https:// doi.org/10.1175/1520-0434(1999)014<0994:SCSEIC>2.0.CO;2.

Walters, B. M. O., 1990: Transmission losses in arid region. J. Hydraul. Eng., 116, 129-138, https://doi.org/10.1061/(ASCE) 0733-9429(1990)116:1(129).

Watson, A. I., R. E. López, and R. L. Holle, 1994: Diurnal cloud-toground lightning patterns in Arizona during the southwest monsoon. Mon. Wea. Rev., 122, 1716-1725, https://doi.org/ 10.1175/1520-0493(1994)122<1716:DCTGLP>2.0.CO;2.

Willingham, K. M., and K. H. Howard, 2010: Characteristics of microbursts in central Arizona. 14th Conf. on Aviation, Range, and Aerospace Meteorology, Atlanta, GA, Amer. Meteor. Soc., 9.1, https://ams.confex.com/ams/90annual/webprogram/ Paper158319.html.

Wood, K. M., and E. A. Ritchie, 2013: An updated climatology of tropical cyclone impacts on the southwestern United States.
Mon. Wea. Rev., 141, 4322-4336, https://doi.org/10.1175/ MWR-D-13-00078.1.

$\longrightarrow$, and - 2014: A 40-year climatology of extratropical transition in the eastern North Pacific. J. Climate, 27, 5999-6015, https://doi.org/10.1175/JCLI-D-13-00645.1.

Woolley, R., R. Marsell, and N. Grover, 1946: Cloudburst floods in Utah, 1850-1938. USGS Water-Supply Paper 994, 128 pp., http://pubs.usgs.gov/wsp/0994/report.pdf.

Yang, L., and J. Smith, 2018: Sensitivity of extreme rainfall to atmospheric moisture content in the arid/semiarid southwestern United States: Implications for probable maximum precipitation estimates. J. Geophys. Res. Atmos., 123, 1638-1656, https://doi.org/10.1002/2017JD027850.

,-- M. L. Baeck, B. Smith, F. Tian, and D. Niyogi, 2016: Structure and evolution of flash flood producing storms in a small urban watershed. J. Geophys. Res. Atmos., 121, 31393152, https://doi.org/10.1002/2015JD024478.

_ M. Liu, J. A. Smith, and F. Tian, 2017a: Typhoon Nina and the August 1975 flood over central China. J. Hydrometeor., 18, 451-472, https://doi.org/10.1175/JHM-D-16-0152.1.

_ J. Smith, M. L. Baeck, E. Morin, and D. C. Goodrich, 2017b: Flash flooding in arid/semi-arid regions: Dissecting the hydrometeorology and hydrology of the 19 August 2014 storm and flood hydroclimatology in Arizona. J. Hydrometeor., 18, 3103-3123, https://doi.org/10.1175/JHM-D-17-0089.1. 